\title{
DIGITALNE ZBIRKE U NARODNIM KNJIŽNICAMA U HRVATSKOJ
}

\section{DIGITAL COLLECTIONS IN PUBLIC LIBRARIES IN CROATIA}

\author{
Katarina Škrabo ${ }^{1}$ \\ Odsjek za informacijske i komunikacijske znanosti \\ Filozofski fakultet Sveučilišta u Zagrebu \\ katarinaskrabo@gmail.com

\section{Radovan Vrana} \\ Odsjek za informacijske i komunikacijske znanosti \\ Filozofski fakultet Sveučilišta u Zagrebu \\ rvrana@ffzg.hr
}

\author{
UDK / UDC 027.3:004.62 \\ Istraživanje / Research \\ Prihvaćeno / Accepted: 11. 5. 2017.
}

\section{Sažetak}

Cilj je rada prikazati rezultate istraživanja dostupnosti i karakteristika digitalnih zbirki u narodnim knjižnicama u Hrvatskoj. Svrha je rada potaknuti stručnu javnost na stvaranje zajedničkih kriterija za razvoj digitalnih zbirki s ciljem olakšavanja pristupa digitalnoj građi korisnicima i potaknuti opću javnost na korištenje postojećih digitalnih zbirki ukazivanjem na njihovu kvalitetu. Rad se sastoji od dva dijela. Prvi dio rada definira narodne knjižnice, digitalne zbirke, digitalne knjižnice i digitalizaciju kao temeljne pojmove rada i kao uvod u drugi dio rada. Drugi dio rada predstavlja rezultate istraživanja, tj. analize i usporedbe svih dostupnih digitalnih zbirki u narodnim knjižnicama u Hrvatskoj. U provedbi istraživanja korištene su metode analize sadržaja i usporedbe na

1 Članak je nastao na temelju diplomskog rada „Digitalne zbirke u narodnim knjižnicama u Republici Hrvatskoj“ autorice Katarine Škrabo, a pod mentorskim vodstvom Radovana Vrane. Katarina Škrabo studentica je Diplomskog studija informacijskih znanosti-smjera bibliotekarstvo na Odsjeku za informacijske i komunikacijske znanosti Filozofskog fakulteta Sveučilišta u Zagrebu.

Vjesnik bibliotekara Hrvatske 60, 1(2017), 103-136

ISSN 0507-1925

(C) VBH 2017. 
temelju unaprijed pripremljenih kriterija čiji je popis nastao analizom sličnosti karakteristika digitalnih zbirki u knjižnicama širom svijeta u pripremnoj fazi istraživanja. Rezultate istraživanja moguće je primijeniti u razvoju budućih digitalnih zbirki, što ujedno predstavlja jednu od aktualnih tema i trajnih aktivnosti knjižnica širom svijeta.

Ključne riječi: narodne knjižnice, digitalizacija, digitalne zbirke, Hrvatska

\section{Summary}

The aim of the paper is to present the results of the research of availability and characteristics of digital collections in public libraries in Croatia. The purpose of the paper is to motivate library professionals to create common criteria for digital collection development with the aim to facilitate access to digital material for users and to motivate general public to use the existing digital collections by pointing out at their quality. The paper consists of two parts. The first part defines public libraries, digital collections, digital libraries, and digitization as fundamental terms of this paper and serves as an introduction into the second part of the paper. The second part of the paper presents the results of the research, i.e. the analysis and comparison of all available digital collections in public libraries in Croatia. Methods used in the second part of the paper are content analysis and comparison of characteristics of digital collections against a set of criteria prepared in advance during the analysis of digital collections across the world in the preparatory phase of the research. The results of the research could be used in further development of user interfaces of future digital collections which is one of the current hot research topics and a permanent orientation of libraries across the world.

Keywords: public libraries, digitization, digital collections, Croatia

\section{Uvod}

Zbog velikog značaja koji su knjižnice imale tijekom povijesnog razvoja društva sve do današnjih dana, odlučili smo istražiti jesu li se narodne knjižnice prilagodile trendovima u suvremenom društvu koje nastoji omogućiti što širi pristup digitalnim izvorima informacija najširim slojevima društva. Kako su narodne knjižnice integralni dio suvremenog društva, one su ujedno i aktivni dionik njegova razvoja u kojem sudjeluju svojim aktivnostima, a koje uključuju razvoj digitalnih zbirki uz čiju se pomoć nastoji pridonijeti povećanju korpusa digitalnih izvora informacija dostupnih putem interneta, obavljajući tako informacijsku, kulturnu i obrazovnu funkciju.

Narodne knjižnice odabrane su za istraživanje zbog svoje široke rasprostranjenosti na teritoriju Hrvatske i dostupnosti svim slojevima stanovništva. UNESCO jasno naglašava glavnu ulogu narodnih knjižnica, koje opisuje kao mjesna i obavi- 
jesna središta koja omogućavaju svim dobnim skupinama pronalazak građe za njihove potrebe. ${ }^{2} \mathrm{U}$ svrhu zadovoljavanja potreba korisnika za informacijama knjižnice se uključuju u stvaranje digitalnih sadržaja svim svojim resursima. Možda i najpoznatiji način stvaranja digitalnih sadržaja u knjižnicama jest digitalizacija dijelova knjižničnih fondova, čime bi se uz postojeću građu u papirnatom formatu privukao i zadržao što veći broj korisnika koji će poželjeti koristiti građu knjižnice u oba formata u samoj zgradi knjižnice ili putem interneta.

Knjižnice u svijetu već su početkom 1990-ih godina prepoznale svoju priliku za uključivanje $u$ aktivnosti povezane sa stvaranjem digitalnih izvora informacija $i$ njihovom organizacijom u obliku digitalnih zbirki te razvojem novih usluga temeljenih na digitalnim zbirkama, pravilno razumjevši kako će im o tome ovisiti budući položaj u društvu. Razvoj digitalnih zbirki predstavlja složen zadatak koji od knjižnica traži visok stupanj organiziranosti, znanje, prostor, dostupnost potrebnih financijskih resursa, opreme i ljudi potrebnih za uspješnu provedbu te aktivnosti. S obzirom na zahtjeve koje je u fazi pripreme digitalizacije potrebno zadovoljiti, većina knjižnica u Hrvatskoj dosad nije pristupila ostvarenju te aktivnosti. ${ }^{3}$

Važnost postupka digitalizacije u stvaranju digitalnih zbirki i proširenju knjižnih fondova u narodnim knjižnicama u Hrvatskoj bila je glavni motiv za pokretanje istraživanja o dostupnosti postojećih digitalnih zbirki u narodnim knjižnicama u Hrvatskoj s ciljem stvaranja cjelovite slike o postojećim digitalnim zbirkama u obliku popisa javno dostupnih digitalnih zbirki i analize karakteristika njihovih korisničkih sučelja kao pomoći knjižničarima i istraživačima u razvoju digitalnih zbirki u narodnim knjižnicama u Hrvatskoj.

\section{Određenje pojmova digitalne zbirke, digitalne knjižnice i digitalizacije}

Temeljni su pojmovi u ovom dijelu rada digitalne zbirke, digitalne knjižnice i digitalizacija. Ti su pojmovi odabrani kao teorijske teme za istraživanje u drugom dijelu rada.

Za Leeja, knjižnična je zbirka akumulacija informacijskih resursa koje su razvili informacijski stručnjaci i namijenili ih korisničkoj zajednici ili korisničkim zajednicama. ${ }^{4}$ Njegova definicija primjenjiva je jednako na tradicionalne knjižnične zbirke temeljene na papirnoj građi kao i na digitalne zbirke temeljene na digitalnoj građi. Lagoze i Fielding otišli su korak dalje i razmatrali pojam zbirke u (digitalnoj) knjižnici te su predložili definiciju digitalne zbirke kao skupa kriterija

\footnotetext{
2 UNESCO-ov manifest za narodne knjižnice 1994. [citirano: 2015-12-03] Dostupno na http:// dzs.ffzg.unizg.hr/text/UNESCOv_manifest_za_narodne_knjiznice.htm.

3 Vrana, Radovan. Vidovi organizacije digitalizacije građe u knjižnicama visokoškolskih ustanova Sveučilišta u Zagrebu. // Vjesnik bibliotekara Hrvatske 55, 2(2012), str. 43.

4 Lee, Hur-Li. What is a collection? // Journal of the American Society for Information Science 51, 12(2000), str. 1106.
} 
za odabir resursa iz šireg informacijskog prostora. ${ }^{5}$ Konkretnija definicija digitalnu zbirku određuje kao vrstu agregacije stvorene postojećim digitalnim objektima ili digitalnim podacima. ${ }^{6} \mathrm{Na}$ temelju svega nekoliko pogleda na pojam digitalne zbirke moguće je uočiti raznolikost pristupa određivanju temeljnih elemenata digitalne zbirke. Ta raznolikost ne treba čuditi jer ni danas ne postoji jedinstven globalni pogled na nastanak digitalnih zbirki i elemente koji ih određuju, premda je moguće uočiti sličnosti između definicija koje ukazuju na digitalne objekte kao temeljnu jedinicu digitalne zbirke, organiziranost kao temeljno načelo razumijevanja odnosa sadržaja digitalne zbirke i agregaciju kao način prikupljanja sadržaja za potrebe stvaranja digitalne zbirke.

Digitalne zbirke mogu postojati kao samostalne cjeline ili mogu biti dijelom digitalnih knjižnica. Prema Manifestu za digitalne knjižnice, „,digitalna knjižnica je online zbirka digitalnih objekata provjerene kvalitete koji su izrađeni ili prikupljeni, kojima se upravlja u skladu s međunarodno prihvaćenim načelima za izgradnju zbirke i koji su dostupni na smislen i održiv način te podržavaju usluge neophodne za omogućivanje dohvaćanja i iskorištavanja izvora korisnicima“". Iz te je definicije moguće vidjeti usmjerenost prema digitalnim objektima kao temeljnoj jedinici digitalne zbirke, postojanje načela organizacije i upravljanja sadržajima digitalne zbirke te agregaciju kroz dohvaćanje izvora.

Digitalizaciju definiramo kao konverziju informacija u digitalni oblik uz pomoć odgovarajućih elektroničkih uređaja kako bi informacije mogle biti obrađene, pohranjene i prenesene uz pomoć digitalne opreme ili mreža. ${ }^{8}$ Kako bi digitalizacija mogla biti uspješno provedena, knjižnica mora osigurati svoje raspoložive resurse i infrastrukturu. Infrastruktura je neophodna u dugoročnim projektima digitalizacije jer podrazumijeva djelovanje politike, tehnologiju, financiranje, stručno znanje i dugoročnu obvezu ustanove. Digitalizacija u knjižnicama ne smije se odvijati uz pomoć improvizacije, pa je takvu aktivnosti potrebno planirati. Planiranje projekta digitalizacije uključuje rješavanje pitanja koja imaju dugoročni utjecaj na provedbu digitalizacije građe, mogućnost njezine ponovne upotrebe, njezinu trajnost, održivost, interoperabilnost, potvrđivanje njezine kvalitete i dokumentiranje provedenih postupaka. ${ }^{9}$

\footnotetext{
5 Lagoze, Carl; Fielding, David. Defining collections in distributed digital libraries. // D-Lib magazine. 4, 11(1998). [citirano: 2017-04-20]. Dostupno na http://www.dlib.org/dlib/november98/ lagoze/11lagoze.html.

6 Digital collection. [citirano: 2017-04-20]. Dostupno na http://smw-rda.esc.rzg.mpg.de/index. php/Digital_Collection.

7 IFLA/Unesco Manifest za narodne knjižnice. // Vjesnik bibliotekara Hrvatske 55, 2(2012), str. 194.

8 Digitization. [citirano: 2017-04-20]. Dostupno na http://www.businessdictionary.com/definition/digitization.html.

9 Vrana, R. Nav. dj. Str. 47.
} 
S porastom popularnosti postupka digitalizacije u svijetu dolazi i do porasta svijesti u knjižnicama o važnosti očuvanja građe koja ima veliku vrijednost u društvu, a za koju do tada uglavnom nisu postojali planovi dugoročnog očuvanja. Digitalizacijom se omogućuje da se krhka, raritetna i unikatna građa, ali i ona građa za kojom postoji jasno iskazana potreba, očuva i učini dostupnom putem interneta. Pritom se najviše misli na građu poput novina, audio-vizualne građe, starih rukopisa, fotografija, povijesnih dokumenata itd. ${ }^{10}$

U literaturi su tijekom posljednja dva desetljeća izdvojeni brojni razlozi za pokretanje postupka digitalizacije. Zbog ograničenog prostora u ovom radu ograničit ćemo se samo na dio razloga koje smo smatrali osobito važnima. Digitalizacija knjižnične građe provodi se radi „zaštite izvornika, povećanja dostupnosti i mogućnosti korištenja građe, radi stvaranja nove ponude, odnosno usluga korisnicima ili pak radi upotpunjavanja postojećega fonda. Svaki od navedenih razloga za digitalizaciju knjižnici postavlja određene zahtjeve koje treba imati u vidu pri planiranju i izvođenju projekata digitalizacije. Vrlo je važno da knjižnice na vrijeme uoče te zahtjeve, procijene njihovu važnost za pojedini projekt i jasno definiraju čime, kako i u kojoj mjeri će njihov krajnji proizvod odgovoriti na pojedini zahtjev.“"11 Koliko knjižnice općenito uspijevaju u ostvarenju postupka digitalizacije i stvaranju digitalnih zbirki, najbolje mogu ocijeniti sami korisnici koji pristupaju i koriste digitalne zbirke. Zbog toga će u nastavku rada biti predstavljeni rezultati analize i usporedbe digitalnih zbirki u narodnim knjižnicama u Hrvatskoj iz perspektive korisnika, a s ciljem stvaranja cjelovite slike o postojećim digitalnim zbirkama u obliku popisa javno dostupnih digitalnih zbirki te analize karakteristika njihovih korisničkih sučelja kao pomoći knjižničarima i istraživačima u razvoju digitalnih zbirki u narodnim knjižnicama u Hrvatskoj.

\section{Analiza i usporedba digitalnih zbirki u narodnim knjižnicama u Hrvatskoj}

U ovom dijelu rada bit će prikazani rezultati istraživanja digitalnih zbirki dostupnih putem interneta u narodnim knjižnicama u Hrvatskoj. Pritom će za provedbu istraživanja biti korištene metode analize sadržaja i usporedbe karakteristika digitalnih zbirki na temelju unaprijed pripremljenih kriterija čiji je popis nastao analizom digitalnih zbirki u knjižnicama širom svijeta u pripremnoj fazi istraživanja. Cilj je istraživanja stvaranje uvida u trenutno stanje dostupnosti digitalnih zbirki u narodnim knjižnicama u Hrvatskoj te utvrđivanje sličnosti i razlika između digitalnih zbirki u svrhu utvrđivanja i odabira temeljnih karakteristika digitalnih zbirki radi lakšeg snalaženja korisnika prilikom njihova ko-

\footnotetext{
10 Isto, str. 45.

11 Isto, str. 10.
} 
rištenja. Uzorak istraživanja određen je pronalaskom svih dostupnih digitalnih zbirki uz pomoć popisa dostupnih digitalnih zbirki na Portalu narodnih knjižnical $^{12}$ i dodatnim lociranjem preostalih dostupnih digitalnih zbirki uz pomoć internetskog pretraživača Google.

\subsection{Analiza podataka o karakteristikama dostupnih digitalnih zbirki na mrežnim stranicama narodnih knjižnica u Hrvatskoj}

Nakon analize dostupnih podataka o karakteristikama postojećih i dostupnih digitalnih zbirki u narodnim knjižnicama u Hrvatskoj prikupljenih pristupom digitalnim zbirkama putem interneta, pristupilo se usporedbi i sistematizaciji podataka te prikazu rezultata u obliku tablica. Analiza i usporedba napravljene su od veljače do svibnja 2016. godine.

U nastavku rada prvo je dan tablični pregled podataka o karakteristikama dostupnih digitalnih zbirki u narodnim knjižnicama u Hrvatskoj. Podaci su razvrstani u tri tablice. U prvoj tablici dan je prikaz podataka o započetom postupku digitalizacije građe i mogućnosti pristupa digitalnoj zbirci putem mrežnih stranica narodne knjižnice kojoj pripada. U drugoj tablici dan je prikaz podataka o vrstama građe dostupnim u digitalnim zbirkama. U posljednjoj tablici navedene su dostupne temeljne funkcije korisničkih sučelja digitalnih zbirki. Na kraju je dana analiza digitalnih zbirki u narodnim knjižnicama u Hrvatskoj po županijama u tekstualnom obliku iz perspektive krajnjeg korisnika.

Grafikoni u ovom dijelu rada dobiveni su analizom sadržaja u dostupnim digitalnim zbirkama.

Tablica 1. Podaci o digitalnim zbirkama u narodnim knjižnicama

\begin{tabular}{|l|l|c|c|}
\hline \multicolumn{4}{|c|}{ Podaci o digitalnim zbirkama u narodnim knjižnicama } \\
\hline & \multicolumn{1}{|c|}{} \\
\multicolumn{1}{|c|}{} & \multicolumn{1}{|c|}{} \\
\hline $\begin{array}{l}\text { Bjelovarsko-bilogorska } \\
\text { županija }\end{array}$ & $\begin{array}{l}\text { Narodna knjižnica "Petar } \\
\text { Preradović" }\end{array}$ & $\mathrm{Da}$ & $\mathrm{Da}$ \\
\hline $\begin{array}{l}\text { Brodsko-posavska } \\
\text { županija }\end{array}$ & $\begin{array}{l}\text { Gradska knjižnica Slavonski } \\
\text { Brod }\end{array}$ & $\mathrm{Da}$ & $\mathrm{Da}$ \\
\hline
\end{tabular}

12 Portal narodnih knjižnica. [citirano: 2016-04-16] Dostupno na http://www.knjiznica.hr/mods/ knjiznice/?zupanija=9. 


\begin{tabular}{|c|c|c|c|}
\hline \multicolumn{4}{|c|}{ Podaci o digitalnim zbirkama u narodnim knjižnicama } \\
\hline : & 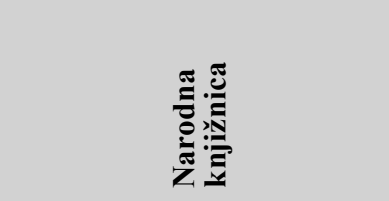 & 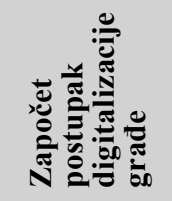 & 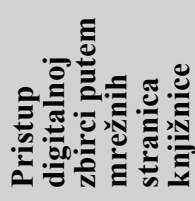 \\
\hline $\begin{array}{l}\text { Dubrovačko- } \\
\text { neretvanska županija }\end{array}$ & $\begin{array}{l}\text { Dubrovačke knjižnice } \\
\text { Dubrovnik }\end{array}$ & $\begin{array}{c}\text { Da } \\
\text { (znanstvena } \\
\text { knjižnica - } \\
\text { iznimka) }\end{array}$ & $\mathrm{Da}$ \\
\hline \multirow{2}{*}{ Istarska županija } & $\begin{array}{l}\text { Gradska knjižnica i čitaonica } \\
\text { Pula }\end{array}$ & $\mathrm{Da}$ & $\mathrm{Da}$ \\
\hline & Gradska knjižnica Poreč & $\mathrm{Da}$ & $\mathrm{Da}$ \\
\hline \multirow{2}{*}{ Karlovačka županija } & $\begin{array}{l}\text { Gradska knjižnica "Ivan } \\
\text { Goran Kovačić" }\end{array}$ & $\mathrm{Da}$ & $\mathrm{Da}$ \\
\hline & $\begin{array}{l}\text { Gradska knjižnica i čitaonica } \\
\text { Ivana Belostenca }\end{array}$ & $\mathrm{Da}$ & $\mathrm{Da}$ \\
\hline \multirow{3}{*}{$\begin{array}{l}\text { Koprivničko- } \\
\text { križevačka županija }\end{array}$} & Gradska knjižnica Đurđevac & $\mathrm{Da}$ & $\mathrm{Da}$ \\
\hline & $\begin{array}{l}\text { Knjižnica i čitaonica "Fran } \\
\text { Galović" Koprivnica }\end{array}$ & $\mathrm{Da}$ & $\mathrm{Da}$ \\
\hline & $\begin{array}{l}\text { Gradska knjižnica "Franjo } \\
\text { Marković" Križevci }\end{array}$ & $\mathrm{Da}$ & $\mathrm{Da}$ \\
\hline $\begin{array}{l}\text { Krapinsko-zagorska } \\
\text { županija }\end{array}$ & Gradska knjižnica Krapina & $\mathrm{Da}$ & $\mathrm{Da}$ \\
\hline Ličko-senjska županija & & $\mathrm{Ne}$ & $\mathrm{Ne}$ \\
\hline Međimurska županija & $\begin{array}{l}\text { Knjižnica i čitaonica Grada } \\
\text { Preloga }\end{array}$ & $\begin{array}{c}\mathrm{Ne} \\
\text { (planiran) }\end{array}$ & $\mathrm{Ne}$ \\
\hline $\begin{array}{l}\text { Osječko-baranjska } \\
\text { županija }\end{array}$ & $\begin{array}{l}\text { Gradska i sveučilišna } \\
\text { knjižnica Osijek }\end{array}$ & $\mathrm{Da}$ & $\mathrm{Da}$ \\
\hline $\begin{array}{l}\text { Požeško-slavonska } \\
\text { županija }\end{array}$ & $\begin{array}{l}\text { Gradska knjižnica i čitaonica } \\
\text { Požega }\end{array}$ & $\mathrm{Da}$ & $\mathrm{Da}$ \\
\hline $\begin{array}{l}\text { Primorsko-goranska } \\
\text { županija }\end{array}$ & Gradska knjižnica Rijeka & $\mathrm{Da}$ & $\mathrm{Da}$ \\
\hline $\begin{array}{l}\text { Sisačko-moslavačka } \\
\text { županija }\end{array}$ & $\begin{array}{l}\text { Narodna knjižnica i čitaonica } \\
\text { Vlado Gotovac Sisak }\end{array}$ & $\mathrm{Da}$ & $\mathrm{Ne}$ \\
\hline \multirow{3}{*}{$\begin{array}{l}\text { Splitsko-dalmatinska } \\
\text { županija }\end{array}$} & Gradska knjižnica Kaštela & $\mathrm{Da}$ & $\mathrm{Ne}$ \\
\hline & Gradska knjižnica Solin & $\mathrm{Da}$ & $\mathrm{Da}$ \\
\hline & $\begin{array}{l}\text { Gradska knjižnica Marko } \\
\text { Marulić Split }\end{array}$ & $\mathrm{Da}$ & $\mathrm{Da}$ \\
\hline
\end{tabular}




\begin{tabular}{|c|c|c|c|}
\hline \multicolumn{4}{|c|}{ Podaci o digitalnim zbirkama u narodnim knjižnicama } \\
\hline 楈 & 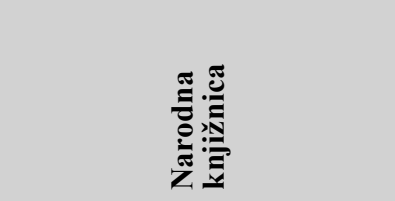 & 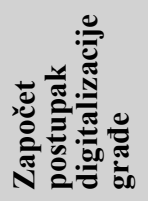 & 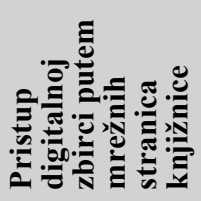 \\
\hline \multirow{3}{*}{ Varaždinska županija } & $\begin{array}{l}\text { Gradska knjižnica i čitaonica } \\
\text { Mladen Kerstner }\end{array}$ & $\mathrm{Da}$ & $\begin{array}{c}\text { Djelomično } \\
\text { (novinama ne } \\
\text { možemo) }\end{array}$ \\
\hline & $\begin{array}{l}\text { Gradska knjižnica i čitaonica } \\
\text { Novi Marof }\end{array}$ & $\mathrm{Da}$ & $\mathrm{Da}$ \\
\hline & $\begin{array}{l}\text { Gradska knjižnica i čitaonica } \\
\text { "Metel Ožegović" }\end{array}$ & $\mathrm{Da}$ & $\mathrm{Da}$ \\
\hline $\begin{array}{l}\text { Virovitičko-podravska } \\
\text { županija }\end{array}$ & $\begin{array}{l}\text { Gradska knjižnica i čitaonica } \\
\text { Virovitica }\end{array}$ & $\mathrm{Da}$ & $\mathrm{Ne}$ \\
\hline $\begin{array}{l}\text { Vukovarsko-srijemska } \\
\text { županija }\end{array}$ & $\begin{array}{l}\text { Gradska knjižnica i čitaonica } \\
\text { Vinkovci }\end{array}$ & $\mathrm{Da}$ & $\mathrm{Da}$ \\
\hline Zadarska županija & Gradska knjižnica Zadar & $\mathrm{Da}$ & $\mathrm{Da}$ \\
\hline Zagrebačka županija & Gradska knjižnica Samobor & $\mathrm{Da}$ & $\mathrm{Da}$ \\
\hline $\begin{array}{l}\text { Šibensko-kninska } \\
\text { županija }\end{array}$ & $\begin{array}{l}\text { Gradska knjižnica "Juraj } \\
\text { Šižgorić” }\end{array}$ & $\mathrm{Da}$ & $\mathrm{Da}$ \\
\hline Grad Zagreb & Knjižnice grada Zagreba & $\mathrm{Da}$ & $\mathrm{Da}$ \\
\hline
\end{tabular}

Tablica 2. Vrste građe dostupne u digitalnim zbirkama narodnih knjižnica

\begin{tabular}{|c|c|c|c|c|c|c|c|c|c|c|c|}
\hline \multicolumn{12}{|c|}{ Vrste građe dostupne u digitalnim zbirkama narodnih knjižnica } \\
\hline 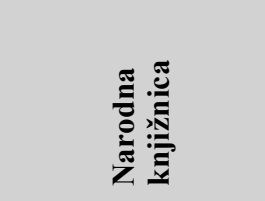 & : & 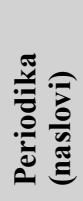 & 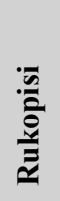 & ש⿺ & 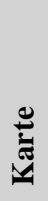 & 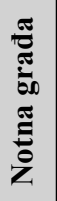 & 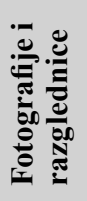 & 总 & 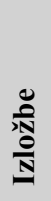 & 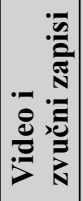 & 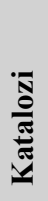 \\
\hline $\begin{array}{l}\text { Narodna knjižnica } \\
\text { "Petar Preradović" }\end{array}$ & 15 & & & & & 10 & 32 & & & 1 & \\
\hline $\begin{array}{l}\text { Gradska knjižnica } \\
\text { Slavonski Brod }\end{array}$ & 72 & 1 & & & & & & & & & \\
\hline $\begin{array}{l}\text { Gradska knjižnica i } \\
\text { čitaonica Pula }\end{array}$ & 12 & & & & & 1 & 124 & & & & \\
\hline $\begin{array}{l}\text { Gradska knjižnica } \\
\text { Poreč }\end{array}$ & 8 & & & & & 1 & 2 & & & & \\
\hline
\end{tabular}




\begin{tabular}{|c|c|c|c|c|c|c|c|c|c|c|c|}
\hline \multicolumn{12}{|c|}{ Vrste građe dostupne u digitalnim zbirkama narodnih knjižnica } \\
\hline 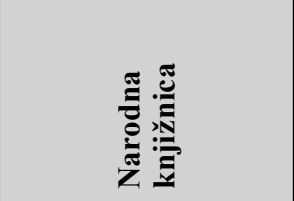 & 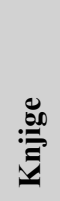 & 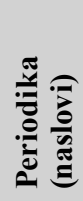 & $\begin{array}{l}\overline{\bar{a}} \\
\overline{\bar{a}} \\
\frac{1}{\bar{a}} \\
\underline{\underline{a}}\end{array}$ & 选 & 䒕 & 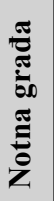 & 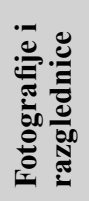 & 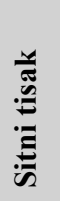 & $\frac{8}{\frac{0}{N}}$ & 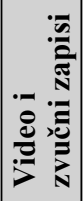 & 昰 \\
\hline $\begin{array}{l}\text { Gradska knjižnica } \\
\text { "Ivan Goran } \\
\text { Kovačić" }\end{array}$ & 3 & 1 & & & & & & & & & \\
\hline $\begin{array}{l}\text { Gradska knjižnica } \\
\text { i čitaonica Ivana } \\
\text { Belostenca }\end{array}$ & 1 & & & & & & & & & & \\
\hline $\begin{array}{l}\text { Gradska knjižnica } \\
\text { Đurđevac }\end{array}$ & & 3 & & & & & & & & & \\
\hline $\begin{array}{l}\text { Knjižnica i čitaonica } \\
\text { "Fran Galović" } \\
\text { Koprivnica }\end{array}$ & 14 & 9 & & & & & 471 & & & & \\
\hline $\begin{array}{l}\text { Gradska knjižnica } \\
\text { "Franjo Marković" } \\
\text { Križevci }\end{array}$ & & & & & & & 129 & & & & \\
\hline $\begin{array}{l}\text { Gradska knjižnica } \\
\text { Krapina }\end{array}$ & & 1 & & & & & & & & & \\
\hline $\begin{array}{l}\text { Gradska i sveučilišna } \\
\text { knjižnica Osijek }\end{array}$ & & 6 & & 7 & 12 & & 164 & & & & 3 \\
\hline $\begin{array}{l}\text { Gradska knjižnica i } \\
\text { čitaonica Požega }\end{array}$ & 23 & & & 10 & & & & & & & \\
\hline $\begin{array}{l}\text { Gradska knjižnica } \\
\text { Rijeka }\end{array}$ & 20 & 264 & & & & & 1034 & & 6 & & \\
\hline $\begin{array}{l}\text { Narodna knjižnica } \\
\text { i čitaonica Vlado } \\
\text { Gotovac Sisak }\end{array}$ & & 1 & & & & & & & & & \\
\hline $\begin{array}{l}\text { Gradska knjižnica } \\
\text { Kaštela }\end{array}$ & 1 & & & & & & & & & & \\
\hline $\begin{array}{l}\text { Gradska knjižnica } \\
\text { Solin }\end{array}$ & 9 & & & & 1 & & & & & & \\
\hline $\begin{array}{l}\text { Gradska knjižnica } \\
\text { Marko Marulić Split }\end{array}$ & 26 & 5 & 3 & & 2 & 1 & 12 & & & 7 & \\
\hline
\end{tabular}




\begin{tabular}{|c|c|c|c|c|c|c|c|c|c|c|c|}
\hline \multicolumn{12}{|c|}{ Vrste građe dostupne u digitalnim zbirkama narodnih knjižnica } \\
\hline 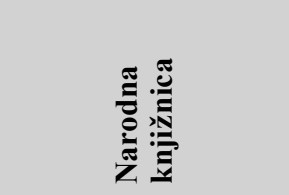 & 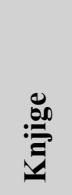 & 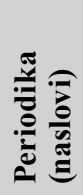 & 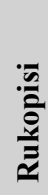 & 音 & 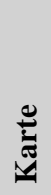 & 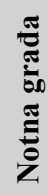 & 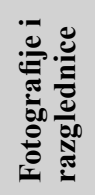 & 范 & 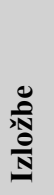 & 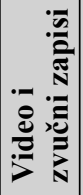 & : \\
\hline $\begin{array}{l}\text { Gradska knjižnica } \\
\text { i čitaonica Mladen } \\
\text { Kerstner }\end{array}$ & & 1 & & & & & 12 & & & & \\
\hline $\begin{array}{l}\text { Gradska knjižnica i } \\
\text { čitaonica Novi Marof }\end{array}$ & 1 & 1 & & & & & & & & & \\
\hline $\begin{array}{l}\text { Gradska knjižnica } \\
\text { i čitaonica "Metel } \\
\text { Ožegović" }\end{array}$ & 453 & 23 & & & & & 312 & & & & \\
\hline $\begin{array}{l}\text { Gradska knjižnica i } \\
\text { čitaonica Virovitica }\end{array}$ & & 1 & & & & & & & & & \\
\hline $\begin{array}{l}\text { Gradska knjižnica i } \\
\text { čitaonica Vinkovci }\end{array}$ & 37 & 4 & & & & & & & & & \\
\hline $\begin{array}{l}\text { Gradska knjižnica } \\
\text { Zadar }\end{array}$ & 18 & & & & & 14 & $\begin{array}{c}13 \\
\text { (slike) }\end{array}$ & & & 60 & \\
\hline $\begin{array}{l}\text { Gradska knjižnica } \\
\text { Samobor }\end{array}$ & & 1 & & & & & & & & & \\
\hline $\begin{array}{l}\text { Gradska knjižnica } \\
\text { "Juraj Šižgorić" }\end{array}$ & & 41 & & & & & & & & & \\
\hline $\begin{array}{l}\text { Knjižnice grada } \\
\text { Zagreba }\end{array}$ & 108 & & 1 & 100 & 2 & 21 & & 21 & & 3 & \\
\hline
\end{tabular}

Tablica 3. Funkcije korisničkih sučelja digitalnih zbirki u narodnim knjižnicama

\begin{tabular}{|l|c|c|c|c|}
\hline \multicolumn{5}{|c|}{ Funkcije korisničkih sučelja digitalnih zbirki u narodnim knjižnicama } \\
\hline Narodna knjižnica & Preuzimanje & Zumiranje & $\begin{array}{c}\text { Pretraživanje } \\
\text { sadržaja po } \\
\text { ključnim } \\
\text { riječima }\end{array}$ & $\begin{array}{c}\text { Prikaz } \\
\text { metapodataka }\end{array}$ \\
\hline $\begin{array}{l}\text { Narodna knjižnica } \\
\text { "Petar Preradović" }\end{array}$ & $\mathrm{Ne}$ & $\mathrm{Da}$ & $\mathrm{Da}$ & $\mathrm{Ne}$ \\
\hline $\begin{array}{l}\text { Gradska knjižnica } \\
\text { Slavonski Brod }\end{array}$ & $\mathrm{Da}$ & $\mathrm{Da}$ & $\mathrm{Da}$ & $\mathrm{Da}$ \\
\hline
\end{tabular}




\begin{tabular}{|c|c|c|c|c|}
\hline \multicolumn{5}{|c|}{ Funkcije korisničkih sučelja digitalnih zbirki u narodnim knjižnicama } \\
\hline Narodna knjižnica & Preuzimanje & Zumiranje & $\begin{array}{l}\text { Pretraživanje } \\
\text { sadržaja po } \\
\text { ključnim } \\
\text { riječima }\end{array}$ & $\begin{array}{c}\text { Prikaz } \\
\text { metapodataka }\end{array}$ \\
\hline $\begin{array}{l}\text { Gradska knjižnica i } \\
\text { čitaonica Pula }\end{array}$ & $\mathrm{Da}$ & $\mathrm{Ne}$ & $\mathrm{Ne}$ & $\mathrm{Ne}$ \\
\hline $\begin{array}{l}\text { Gradska knjižnica } \\
\text { Poreč }\end{array}$ & $\mathrm{Da}$ & $\mathrm{Da}$ & $\mathrm{Ne}$ & $\mathrm{Ne}$ \\
\hline $\begin{array}{l}\text { Gradska knjižnica } \\
\text { "Ivan Goran } \\
\text { Kovačić" }\end{array}$ & $\mathrm{Da}$ & $\mathrm{Da}$ & $\mathrm{Ne}$ & $\mathrm{Ne}$ \\
\hline $\begin{array}{l}\text { Gradska knjižnica } \\
\text { i čitaonica Ivana } \\
\text { Belostenca }\end{array}$ & $\mathrm{Da}$ & $\mathrm{Da}$ & $\mathrm{Ne}$ & $\mathrm{Ne}$ \\
\hline $\begin{array}{l}\text { Gradska knjižnica } \\
\text { Đurđevac }\end{array}$ & $\mathrm{Ne}$ & $\mathrm{Da}$ & $\mathrm{Ne}$ & $\mathrm{Ne}$ \\
\hline $\begin{array}{l}\text { Knjižnica i čitaonica } \\
\text { "Fran Galović" } \\
\text { Koprivnica }\end{array}$ & $\mathrm{Da}$ & $\mathrm{Da}$ & $\begin{array}{c}\text { Da } \\
\text { (za digitalna } \\
\text { izdanja) }\end{array}$ & $\begin{array}{c}\mathrm{Da} \\
\text { (za razglednice) }\end{array}$ \\
\hline $\begin{array}{l}\text { Gradska knjižnica } \\
\text { "Franjo Marković" } \\
\text { Križevci }\end{array}$ & $\mathrm{Da}$ & $\mathrm{Da}$ & $\mathrm{Da}$ & $\mathrm{Ne}$ \\
\hline $\begin{array}{l}\text { Gradska knjižnica } \\
\text { Krapina }\end{array}$ & $\mathrm{Ne}$ & $\mathrm{Ne}$ & $\mathrm{Ne}$ & $\mathrm{Ne}$ \\
\hline $\begin{array}{l}\text { Gradska i sveučilišna } \\
\text { knjižnica Osijek }\end{array}$ & $\mathrm{Da}$ & $\mathrm{Da}$ & $\mathrm{Ne}$ & $\mathrm{Da}$ \\
\hline $\begin{array}{l}\text { Gradska knjižnica i } \\
\text { čitaonica Požega }\end{array}$ & $\mathrm{Ne}$ & $\mathrm{Da}$ & $\mathrm{Da}$ & $\mathrm{Da}$ \\
\hline $\begin{array}{l}\text { Gradska knjižnica } \\
\text { Rijeka }\end{array}$ & $\mathrm{Da}$ & $\mathrm{Da}$ & $\mathrm{Da}$ & $\mathrm{Da}$ \\
\hline $\begin{array}{l}\text { Narodna knjižnica } \\
\text { i čitaonica Vlado } \\
\text { Gotovac Sisak }\end{array}$ & $\mathrm{Da}$ & $\mathrm{Ne}$ & $\mathrm{Ne}$ & $\mathrm{Ne}$ \\
\hline $\begin{array}{l}\text { Gradska knjižnica } \\
\text { Kaštela }\end{array}$ & $\mathrm{Da}$ & $\mathrm{Da}$ & $\mathrm{Da}$ & $\mathrm{Ne}$ \\
\hline $\begin{array}{l}\text { Gradska knjižnica } \\
\text { Solin }\end{array}$ & $\mathrm{Ne}$ & $\mathrm{Da}$ & $\mathrm{Da}$ & $\mathrm{Ne}$ \\
\hline $\begin{array}{l}\text { Gradska knjižnica } \\
\text { Marko Marulić Split }\end{array}$ & $\mathrm{Ne}$ & $\mathrm{Da}$ & $\mathrm{Da}$ & $\mathrm{Da}$ \\
\hline
\end{tabular}




\begin{tabular}{|l|c|c|c|c|}
\hline \multicolumn{4}{|c}{ Funkcije korisničkih sučelja digitalnih zbirki u narodnim knjižnicama } \\
\hline Narodna knjižnica & Preuzimanje & Zumiranje & $\begin{array}{c}\text { Pretraživanje } \\
\text { sadržaja po } \\
\text { ključnim } \\
\text { riječima }\end{array}$ & $\begin{array}{c}\text { Prikaz } \\
\text { metapodataka }\end{array}$ \\
\hline $\begin{array}{l}\text { Gradska knjižnica } \\
\text { i čitaonica Mladen } \\
\text { Kerstner }\end{array}$ & $\mathrm{Ne}$ & $\mathrm{Da}$ & $\mathrm{Ne}$ & $\mathrm{Ne}$ \\
\hline $\begin{array}{l}\text { Gradska knjižnica i } \\
\text { čitaonica Novi Marof }\end{array}$ & $\mathrm{Da}$ & $\mathrm{Da}$ & $\mathrm{Ne}$ & $\mathrm{Da}$ \\
\hline $\begin{array}{l}\text { Gradska knjižnica } \\
\text { i čitaonica "Metel } \\
\text { Ožegović” }\end{array}$ & $\mathrm{Ne}$ & $\mathrm{Da}$ & $\mathrm{Da}$ & (za razglednice) \\
\hline $\begin{array}{l}\text { Gradska knjižnica i } \\
\text { čitaonica Virovitica }\end{array}$ & $\mathrm{Ne}$ & $\mathrm{Da}$ & $\mathrm{Ne}$ & $\mathrm{Ne}$ \\
\hline $\begin{array}{l}\text { Gradska knjižnica i } \\
\text { čitaonica Vinkovci }\end{array}$ & $\mathrm{Ne}$ & $\mathrm{Da}$ & $\mathrm{Da}$ & $\mathrm{Ne}$ \\
\hline $\begin{array}{l}\text { Gradska knjižnica } \\
\text { Zadar }\end{array}$ & $\mathrm{Da}$ & $\mathrm{Da}$ & $\mathrm{Da}$ & $\mathrm{Ne}$ \\
\hline $\begin{array}{l}\text { Gradska knjižnica } \\
\text { Samobor }\end{array}$ & $\begin{array}{c}\mathrm{Da} \text { (potrebna } \\
\text { pismena dozvola } \\
\text { knjižnice) }\end{array}$ & $\mathrm{Da}$ & $\mathrm{Ne}$ & $\mathrm{Ne}$ \\
\hline $\begin{array}{l}\text { Gradska knjižnica } \\
\text { "Juraj Šižgorić” }\end{array}$ & $\mathrm{Da}$ & $\mathrm{Da}$ & $\mathrm{Da}$ & $\mathrm{Ne}$ \\
\hline $\begin{array}{l}\text { Knjižnice grada } \\
\text { Zagreba }\end{array}$ & $\mathrm{Da}$ & $\mathrm{Da}$ & $\mathrm{Na}$ \\
\hline
\end{tabular}

\subsection{Analiza dostupnih digitalnih knjižničnih zbirki po županijama}

Projekti digitalizacije započeti su u svim većim narodnim knjižnicama u hrvatskim županijama. Najviše projekata digitalizacije, po tri, započeto je u Koprivničko-križevačkoj, Splitsko-dalmatinskoj i Varaždinskoj županiji. Po dva projekta digitalizacije započeta su u Istarskoj i Karlovačkoj županiji. Projekt digitalizacije građe započet je i u Dubrovačko-neretvanskoj županiji. Projekt se odnosi na znanstvenu knjižnicu, iako mu se može pristupiti putem mrežne stranice narodne knjižnice. Postupak digitalizacije jedino nije započet u Ličko-senjskoj županiji, dok Međimurska županija nema digitaliziranu građu dostupnu na mrežnim stranicama narodnih knjižnica, ali je započela priprema za digitalizaciju građe. Po jedan projekt digitalizacije započet je u ostalim županijama.

U nastavku rada slijedi analiza dostupnih digitalnih zbirki iz perspektive korisnika. Dostupne digitalne zbirke poredane su po županijama. 


\section{Bjelovarsko-bilogorska županija}

\section{Narodna knjižnica „Petar Preradović““}

Narodna knjižnica „Petar Preradović“ Bjelovar ima dostupnu digitaliziranu građu koja se nalazi na mrežnoj stranici Knjižnice pod izbornikom Digitalna knjižnica. Posebna pozornost u Digitalnoj knjižnici pridana je zbirci Petar Preradović. ${ }^{13}$

Pod izbornikom Digitalna knjižnica nalazi se petnaest digitaliziranih jedinica pod pet naslova koji su navedeni jedni ispod drugih. Dostupne su putem knjižničnog programa Metelwin. Digitaliziranu građu moguće je zumirati i pretraživati po ključnim riječima, ali ju nije moguće pohraniti. Sam izbornik Digitalna knjižnica trebao biti bolje organiziran. Trebala bi postojati jasna oznaka za digitaliziranu građu, a ne da se građa nalazi navedena ispod ostalih usluga digitalne knjižnice bez jasne oznake. Jer kada se gleda izbornik „Digitalna knjižnica“, digitalizirane zbirke doimaju se kao poveznice na neke druge usluge, a ne digitalna građa. ${ }^{14}$

Posljednja se navodi zbirka Petar Preradović, koja bi mogla biti bolje istaknuta na mrežnim stranicama knjižnice. Na posebnoj mrežnoj stranici zbirke možemo saznati o životu i stvaralaštvu tog našeg pjesnika, čitati i slušati njegove pjesme, pregledati fotografije i riješiti kviz. Stranica je lijepo uređena, međutim slova su presitna. Svaka slika koja je digitalizirana u sklopu pojedine kategorije automatski se pohranjuje na računalo jednim klikom na nju. Isto vrijedi i za notne zapise i ostale primjere zapisa koje možemo pronaći na stranici. ${ }^{15}$

\section{Brodsko-posavska županija}

\section{Gradska knjižnica Slavonski Brod}

Na početnoj stranici Gradske knjižnice Slavonski Brod moguće je pristupiti digitalnoj zavičajnoj zbirci pod nazivom Brodensia. ${ }^{16}$ Projekt digitalizacije knjiga i ostale knjižnične građe započet je 2015. godine. Projektom se željelo prikazati povijest i razvoj lokalne zajednice u vremenu duljem od sto godina. Digitalni repozitorij Brodensia nastao je konverzijom različitih pisanih, slikovnih i ostalih izvornika u nov oblik digitalnog zapisa i moguće je njegovo trajno nadopunjavanje. ${ }^{17}$

Klikom na Brodensiu imamo pristup zbirci časopisa i knjiga. Stranica je dobro organizirana i vizualno dotjerana. U zbirci časopisa možemo pristupiti Prilozima za upoznavanje Broda i okolice I. Časopis se može pregledavati na internetskoj strani-

\footnotetext{
13 Narodna knjižnica „Petar Preradović“ Bjelovar. [citirano: 2016-04-13] Dostupno na http:// www.knjiznica-bjelovar.hr/index.php/o_nama/.

14 Isto.

15 Isto.

16 Gradska knjižnica Slavonski Brod. [citirano: 2016-05-11] Dostupno na http://www.gksb.hr/.

17 Brodensia, zavičajna zbirka. [citirano: 2016-05-11] Dostupno na http://www.brodensia.hr/index.php/o-projektu.
} 
ci, a možemo ga i automatski pohraniti na računalo te sadrži metapodatke. Od knjiga su digitalizirana ukupno 72 naslova koje možemo pretraživati po naslovu i autoru. ${ }^{18}$

\section{Dubrovačko-neretvanska županija Narodna knjižnica Grad}

Mrežna stranica Dubrovačke knjižnice na jednom mjestu pohranjuje informacije vezane uz njihovu Narodnu knjižnicu Grad i Znanstvenu knjižnicu. Putem mrežne stranice pod izbornikom Projekti možemo pristupiti digitalnom projektu znanstvene, a ne narodne knjižnice. Projekt digitalizacije građe znanstvene knjižnice Zavičajne zbirke Ragusina započeo je 2014. godine i u potpunosti je obuhvatio dvije najtraženije zbirke periodike: Crvena Hrvatska i Karnevalski listovi. Ukupno je digitalizirano 1457 brojeva Crvene Hrvatske i 102 izdanja Karnevalskih listova. O projektu dalje neće biti govora jer se odnosi na znanstvenu knjižnicu, iako se njihovim izdanjima može pristupiti putem mrežne stranice narodne knjižnice. ${ }^{19}$

\section{Istarska županija}

\section{Gradska knjižnica i čitaonica Pula}

Na mrežnim stranicama Gradske knjižnice i čitaonice Pula možemo pronaći digitaliziranu zavičajnu zbirku. Projekt digitalizacije započeo je 2009. godine jer je Knjižnica željela zaštiti građu, osigurati dostupnost te pružiti pristup i informacije korisnicima o zavičajnom kulturnom nasljeđu grada, okolice i Istre. Građa zavičajne zbirke služi promidžbi i vrednovanju zavičajnog kulturnog identiteta, kao i promociji istarske baštine. Projektom je predstavljena građa koja se ne može posuditi izvan knjižnice. ${ }^{20}$

Stranica je vizualno uređena i laka za snalaženje. Za digitalizaciju je prvo odabrana zbirka starih razglednica. Na stranici Knjižnice možemo vidjeti 124 digitalizirane razglednice s motivima Pule od kraja 19. stoljeća do 30-ih godina 20. stoljeća. Uz razglednice, digitalizirana je i zbirka notnih zapisa narodnih popijevki Hrvatske narodne popijevke iz Istre, koja je bila objavljena 1910. godine u Puli. ${ }^{21}$

Uz navedenu građu, omogućen je i pristup do 12 digitaliziranih knjiga koje je moguće samo prelistavati. Knjige su poprilično vjerno digitalizirane, ali ne u potpunosti jer nedostaju neke stranice. Obrada građe rađena je u digitalnom okruženju Dublin Core kako bi se omogućila komunikacija s Europeanom. ${ }^{22}$

\footnotetext{
18 Isto.

19 Dubrovačke knjižnice Dubrovnik. [citirano: 2016-04-14] Dostupno na http://www.dkd.hr/ index.php?option=com_content\&view $=$ article \&id=355\&Itemid $=192$.

20 Virtualna zavičajna zbirka. Projekt Gradske knjižnice i čitaonice Pula. [citirano: 2016-04-14]

Dostupno na http://vizz.gkc-pula.hr/hr/o-projektu/.

21 Isto.

22 Isto.
} 


\section{Gradska knjižnica Poreč}

U Gradskoj knjižnici Poreč 2002. godine započeta je digitalizacija građe, a tom je prilikom izrađen CD-ROM Pozice uz tiskano izdanje zbirke literarnih i likovnih radova Pozica. Knjižnica Poreč od 2009. je godine prva narodna knjižnica u Istri koja je imala dostupna digitalizirana izdanja na internetu. Cilj projekta bio je omogućiti dostupnost tekstualnih, slikovnih i audiozapisa, a osobito značajnih kulturnih vrijednosti zavičajne baštine porečkog kraja. Za prvu digitalizaciju odabrana je publikacija Srdačno vaš Poreč jer se putem zavičajne građe željelo promovirati kulturni lokalitet. ${ }^{23}$

Mrežnu stranicu digitalne knjižnice potrebno je doraditi. Za pretraživanje nam je ponuđen izbornik Knjige pod kojim se nalazi i ostala digitalizirana građa. Do sada je digitalizirano osam knjiga, jedne note i dvije razglednice koje možemo zumirati, pretraživati po ključnim riječima i pohraniti na računalo. Međutim tri knjige nije moguće učitati. ${ }^{24}$

\section{Karlovačka županija}

\section{Gradska knjižnica „Ivan Goran Kovačić““}

U Gradskoj knjižnici „Ivan Goran Kovačićc Karlovac pod izbornikom Digitalna knjižnica možemo pristupiti Digitaliziranoj karlovačkoj baštini u kojoj je moguće proučiti digitaliziranu građu: Tri siela narodne čitaonice karlovačke (obrazovno - povjestna crta uz svjetlopisne slike na prvoj izložbi trojedne kraljevine izložena 1864.), Upisana knjiga posjetilaca Ilirske čitaonice u Karlovcu i knjigu Grad Karlovac i njegova okolica. Sama stranica vizualno je uređena i laka za snalaženje. Građa je vjerno digitalizirana i moguće ju je pohraniti na računalo. ${ }^{25}$

Na mrežnoj stranici postoji i izbornik Digitalizirani karlovački tisak koji sadrži članke o Domovinskom ratu iz časopisa Svjetlo i digitalizirani Karlovački tjednik. Dostupni članci iz časopisa Svjetlo mogu se zumirati, pregledavati po ključnim riječima i pohraniti na računalo. Međutim problem nastaje kada želimo pregledati Karlovački tjednik. Za njegov pregled potrebno je instalirati Microsoft Silverlight jer u suprotnom ne možemo vidjeti digitaliziranu građu. Međutim i nakon instalacije Microsoft Silverlighta vidi se samo prva stranica tjednika, a kada želimo prijeći na iduću, sve postaje crno. Tek se nakon nekoliko minuta učita tekst, što je neprihvatljivo u usporedbi s ostalim mrežnim stranicama gdje se nalazi digitalizirana građa koja se učitava bez duljeg čekanja. ${ }^{26}$

\footnotetext{
23 Gradska knjižnica Poreč. [citirano: 2016-04-14] Dostupno na http://porec.arhivpro.hr/index. php.

24 Isto.

25 Gradska knjižnica „Ivan Goran Kovačić“. [citirano: 2016-04-14] Dostupno na http://www. gkka.hr/?page_id=975.

26 Isto.
} 


\section{Gradska knjižnica i čitaonica Ivana Belostenca}

Gradska knjižnica i čitaonica Ivana Belostenca u Ozlju ima digitaliziranu građu pod nazivom Gazophylacium. Građa je dobila ime po najvećem djelu Ivana Belostenca, a radi se o dvojezičnom i dvoknjižnom latinsko-hrvatskom rječniku. Belostenec je smatrao taj rječnik svojim životnim djelom i radio je na njemu sve do smrti. Rječnik nije uspio završiti, pa se 65 godina nalazio u rukopisu u pavlinskom samostanu. Djelo je vjerno digitalizirano, a moguće ga je zumirati i pohraniti na računalo. ${ }^{27}$

\section{Koprivničko-križevačka županija}

\section{Gradska knjižnica Đurđevac}

Na mrežnim stranicama Gradske knjižnice Đurđevac možemo pronaći arhivu đurđevačkih novina. Projektom je digitalizirano 59 brojeva novina Podravec (1991.-1992.), 72 broja Đurđevačkog vjesnika (1952.-1969.) i 4 broja Novog Podravca (1953.). Sama stranica dosta je jednostavna i laka za snalaženje, ali bi ju trebalo malo doraditi jer izgleda kao isječak iz novina, a slova su dosta sitna. Građa je dostupna putem knjižničnog programa Metelwin. Novine su vjerno digitalizirane. Mogu se zumirati, ali se ne mogu pretraživati po ključnim riječima i pohraniti na računalo. ${ }^{28}$

\section{Knjižnica i čitaonica „Fran Galović”}

\section{Koprivnica}

Na mrežnoj stranici Knjižnice i čitaonice „Fran Galović” Koprivnica nalazi se poveznica na digitaliziranu građu, dokumente i isprave, djela Frana Galovića i razglednice. Digitalizirana građa dostupna je putem knjižničnog programa Metelwin. Projekt je započeo 2007. godine u okviru projekata Digitalizacija zavičajne kulturne baštine i Hrvatska kulturna baština koje je provodilo Ministarstvo kulture Republike Hrvatske. ${ }^{29}$

Digitalna građa podijeljena je u dva izbornika:

a) Koprivnički zavičajni projekti digitalizacije:

1. Koprivnička kulturna baština

2. Digitalizirane razglednice

3. Fran Galović online

\footnotetext{
27 Gradska knjižnica i čitaonica Ivana Belostenca. [citirano: 2016-04-14] Dostupno na http:// www.gkc-ivanabelostenca.hr/index.php/o-nama.

28 Novinstvo Đurđevca. Gradska knjižnica Đurđevac. [citirano: 2016-04-14] Dostupno na http://library.foi.hr/dj/upit.aspx.

29 Knjižnica Fran Galović Koprivnica. [citirano: 2016-04-14] Dostupno na http://www.knjiznica-koprivnica.hr/knjiznica/defaultcont.asp?id=11\&n=5.
} 
4. Digitalizirani koprivnički tisak

5. Digitalizirana građa Glasa Podravine

b) Digitalna izdanja knjižnice:

1. Zbornik radova "Knjižnična usluga za slijepe i slabovidne : stanje i perspektive"

2. Katalog izložbe "Tražimo najstariju slikovnicu u Koprivnici"

3. Bibliobus za mene znači sreću

4. Koprivnica - slikovnica ${ }^{30}$

Koprivnički zavičajni projekt digitalizacije obuhvaća 31 digitalnu zbirku Koprivničke kulturne baštine, 14 knjiga, 471 razglednicu iz 2 zbirke, 9 digitaliziranih novina koprivničkog tiska i digitalizirane brojeve Glasa Podravine od 1950. do 2007. godine (slika 1). Građa je vjerno digitalizirana, ali ima nekih nedostataka. Razglednice možemo zumirati i imamo metapodatke za njih, ali ih ne možemo pohraniti na računalo, dok pojedine novine ne možemo pročitati na pregibima gdje su bile izvorno presavijene. ${ }^{31}$

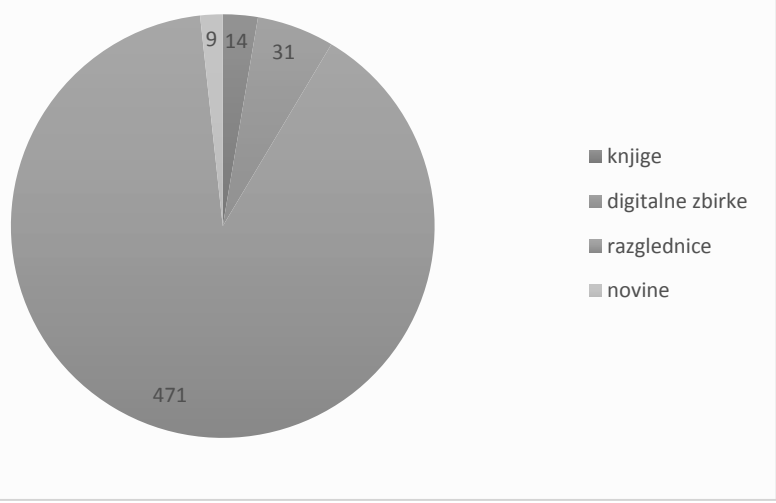

Slika 1. Digitalizirana građa u Knjižnici i čitaonici „Fran Galovič” Koprivnica

Knjižnica je posebnu pozornost dala zbirci Frana Galovića, hrvatskog književnika moderne. Mrežna stranica na kojoj se nalazi uređena je, a sama je građa vjerno digitalizirana. Moguće ju je zumirati i pohraniti na računalo. ${ }^{32}$

Digitalna izdanja Knjižnice imaju po jedan primjerak ranije navedene građe. Građu je moguće zumirati i pretraživati po ključnim riječima. ${ }^{33}$

30 Isto.

31 Isto.

32 Isto.

33 Isto. 


\section{Gradska knjižnica „Franjo Marković” Križevci}

Gradska knjižnica „Franjo Marković” Križevci na mrežnoj stranici ima zavičajnu zbirku Crisiensia. Knjižnica trenutno radi na projektu izrade digitalne hemeroteke. Na mrežnoj stranici knjižnice možemo pristupiti probnoj verziji koja obuhvaća novinske članke od 2001. do 2008. godine. ${ }^{34}$ Projekt se odnosi na digitalizaciju članaka iz dnevnog tiska koji se odnose na Križevce i okolicu. Do sada su na CD-ROM-u digitalizirani novinski izresci za godine 1975.-1978. Knjižnica planira digitalizirati cjelokupnu zbirku hemeroteke od 1975. do danas. ${ }^{35}$

Pretraživanjem hemeroteke možemo pristupiti novinskim člancima koji su prikazani u digitaliziranom obliku, a ispod članka nalazi se pretipkan tekst kako bi korisnicima sve bilo čitljivije. Sve je vjerno digitalizirano, a isječke i razglednice moguće je zumirati, pretraživati po ključnim riječima i pohraniti na računalo. ${ }^{36}$

Krapinsko-zagorska županija

\section{Gradska knjižnica Krapina}

Gradska knjižnica Krapina započela je s projektom digitalizacije Krapinskog vjesnika, lokalnih novina koje su izlazile od 1979. do 1989. godine. Novine su pratile gospodarske, kulturne, političke i ostale aspekte života krapinske zajednice. Knjižnica se odlučila na projekt digitalizacije jer su se izvorni primjerci željeli očuvati od oštećivanja, ali i učiniti dostupnijima. Ukupno je skenirano svih 205 brojeva s preko 2500 stranica. Na mrežnoj stranici dostupni su brojevi od 1979. do 1986. godine. Za pregled je potrebno imati Microsoft Silverlight, koji i u ovom slučaju ne radi dobro. ${ }^{37}$

\section{Ličko-senjska županija}

Na području Ličko-senjske županije nije započet nijedan postupak digitalizacije u narodnim knjižnicama. ${ }^{38}$

\section{Međimurska županija}

U međimurskoj županiji ne postoji nijedna narodna knjižnica u kojoj je dostupna digitalna građa u sklopu narodne knjižnice. Planirana je digitalizacija knjižnične građe u Knjižnici i čitaonici Grada Preloga o donjem Međimurju u sklopu projekta Pučka pobožnost i predajna etnobaština na tlu donjeg Međimurja kako bi se predstavila i popularizirala etnološka i ostala građa o donjem Međimurju. ${ }^{39}$

\footnotetext{
34 Gradska knjižnica „Franjo Marković“ Križevci. [citirano: 2016-04-14] Dostupno na http:// www.knjiznica-krizevci.hr/html.asp?id=1310.

35 Isto.

36 Isto.

37 Gradska knjižnica Krapina. [citirano: 2016-04-16] Dostupno na http://krapina.arhivpro.hr/index.php.

38 Portal narodnih knjižnica. [citirano: 2016-04-16] Dostupno na http://www.knjiznica.hr/mods/ knjiznice/?zupanija=9.

39 Knjižnica i čitaonica Grada Preloga. [citirano: 2016-04-16] Dostupno na http://knjiznica-prelog.webs.com/.
} 
Osječko-baranjska županija

Gradska i sveučilišna knjižnica Osijek

Gradska i sveučilišna knjižnica Osijek omogućuje pristup svojoj digitalnoj knjižnici putem svoje službene stranice. Digitalna knjižnica sadrži vrijednu i rijetku građu osječkoga kraja. Građa je pohranjena u zbirkama i odjelima Knjižnice. Digitalnom knjižnicom željelo se riješiti problem nedovoljne dostupnosti građe svojim korisnicima, ali i onim potencijalnima. Željelo se omogućiti pristup građi kojoj je bilo teško pristupiti te interaktivan rad na dokumentima i zbirkama, bez obzira na to na kojoj se lokaciji nalaze. ${ }^{40}$

U dijagramu vidimo popis digitalizirane građe i broj primjeraka (slika 2). ${ }^{41}$

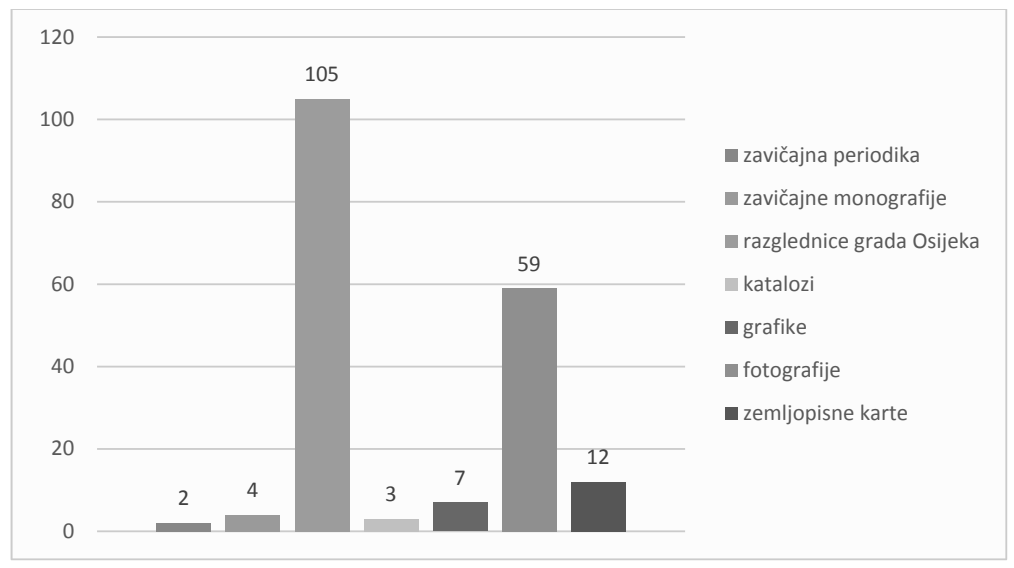

Slika 2. Digitalizirana građa u Gradskoj i sveučilišnoj knjižnici Osijek

U zavičajnoj periodici započeo je projekt digitalizacije tjednikom Osječka pozornica. Bio je to tjednik Hrvatskog državnog kazališta u Osijeku, koji je izlazio u razdoblju od 1941. do 1944. godine. Projekt digitalizacije nastavljen je digitalizacijom časopisa Hrvatska pčela. Projekt digitalizacije časopisa započeo je u Knjižnici 2011. godine, povodom 130. godišnjice početka izlaženja. ${ }^{42}$

Gradska i sveučilišna knjižnica Osijek pokrenula je 2014. godine projekt digitalizacije Književne baštine Rudolfa Franjina Magjera. Projektom je željela doprinijeti Hrvatskoj kulturnoj baštini, nacionalnom projektu digitalizacije arhivske, knjižnične i muzejske građe, koji se odvija pod pokroviteljstvom Ministarstva kulture Republike Hrvatske. Na službenoj stranici imamo pristup Magjerovoj autobiografiji, a tu su i 33 književna rada, 7 pisama, ostali izvori o Magjeru i književna

\footnotetext{
40 Gradska i sveučilišna knjižnica Osijek. [citirano: 2016-02-15] Dostupno na http://www. gskos.unios.hr/?upit=sadrzaj\&id=191.

41 Isto.

42 Isto.
} 
kritika prof. Mate Božičevića. Službena stranica o Magjerovu životu još je uvijek u nastajanju te svi planirani sadržaji još nisu vidljivi na njezinu sučelju. ${ }^{43}$

Požeško-slavonska županija

Gradska knjižnica i čitaonica Požega

Da bi se približila svojim korisnicima, Gradska knjižnica i čitaonica Požega započela je 2009. godine projekt digitalizacije stare i rijetke građe Possegana koja je bila pohranjena u zbirkama i odjelima Knjižnice. ${ }^{44}$

Zbirku digitalnih izdanja raritetnih knjiga iz zavičajne zbirke Possegana čine:

1. Ilirska slovnica, djelo Vjekoslava Babukića iz 1854. godine

2. Iz mladieh lietah, djelo Ivana Napoleona Špun-Strižića iz 1866. godine

3. Požega, djelo Julija Kempfa iz 1910. godine. ${ }^{45}$

U Knjižnici su digitalizirane 33 vrste građe koje možemo vidjeti u dijagramu (slika 3$).{ }^{46}$

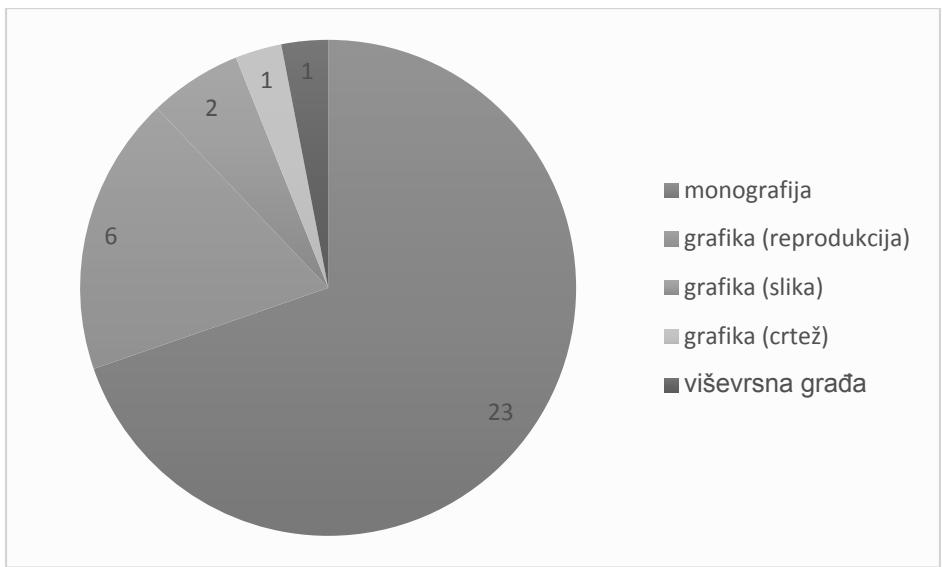

Slika 3. Digitalizirana građa u Gradskoj knjižnici i čitaonici Požega

Digitaliziranu građu moguće je pretraživati po ključnim riječima i zumirati, sadrži metapodatke, ali ju nije moguće pohraniti na računalo. Pretraživanje se obavlja putem Metelwina. ${ }^{47}$

\footnotetext{
43 Književna baština R. F. Magjera. [citirano: 2016-02-15] Dostupno na http://magjer.gskos.hr/.

44 Gradska knjižnica i čitaonica Požega. [citirano: 2016-02-15] Dostupno na http://www.gkpz. $\mathrm{hr} /$ digitalna-bastina/.

45 Isto.

46 Isto.

47 Isto.
} 
Putem mrežne stranice Knjižnice možemo pristupiti i Knjižnici Julija Kempfa koja nam prikazuje dvadeset djela koja je Kempf posjedovao. Knjižnica je 2009. godine dobila u posjed Kempfove knjige povodom 145. obljetnice njegova rođenja i 75. obljetnice smrti. Također, možemo vidjeti i uskrsne čestitke i razglednice iz ostavštine obitelji Kempf, njih ukupno $24 .{ }^{48}$

Primorsko-goranska županija

Gradska knjižnica Rijeka

Na mrežnoj stranici Gradske knjižnice Rijeka dostupna je digitalna knjižnica SveVid. SveVid okuplja digitalizirane i digitalno nastale objekte koji se odnose na zavičajnu zbirku, stručnu literaturu i stručna postignuća djelatnika Knjižnice. Tako na jednom mjestu imamo pristup knjigama, razglednicama, novinama i časopisima te virtualne izložbe. ${ }^{49}$

Digitalna knjižnica napravljena je u programu otvorenog koda Omeka koji podržava međunarodne standarde podataka i njihove razmjene jer se želi postići da se digitalni objekti lakše uključe u vanjske usluge poput Europeane..$^{50}$

U Knjižnici se nalazi 1324 jedinica digitalne građe koje možemo vidjeti u dijagramu (slika 4). ${ }^{51}$ Sadržaj je moguće zumirati, pretraživati po ključnim riječima i pohraniti na računalo, a sadrži metapodatke. Jedan dio građe na talijanskom je jeziku, a sama građa prilično je vjerno digitalizirana. ${ }^{52}$

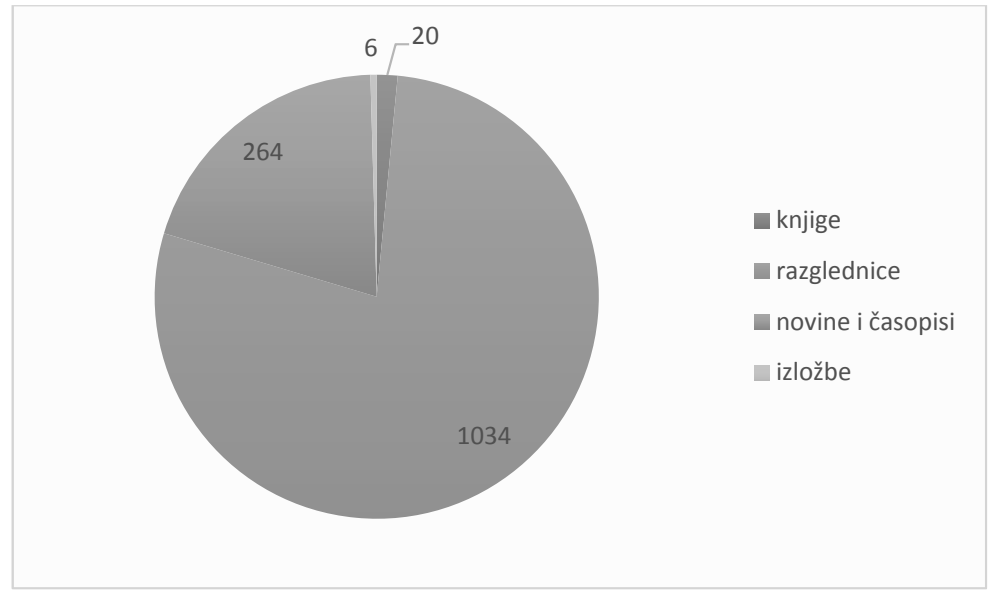

Slika 4. Digitalna građa u Gradskoj knjižnici Rijeka

\footnotetext{
48 Isto.

49 SVeVID digitalna knjižnica. [citirano: 2016-04-16] Dostupno na https://svevid.locloudhosting.net/.

50 Isto.

51 Isto.

52 Isto.
} 
Sisačko-moslavačka županija

\section{Narodna knjižnica i čitaonica Vlado Gotovac Sisak}

Narodna knjižnica i čitaonica Vlado Gotovac Sisak pokrenula je projekt digitalizacije tjednika Jedinstvo. Tjednik je izlazio od 1953. do 1992. Godine 1992. tjednik mijenja ime u Sisački tjednik, a 1998. u Novi sisački tjednik. Knjižnica je jedna od rijetkih ustanova koje čuvaju tu građu, pa je projekt pokrenut kako bi se građa sačuvala, ali i ostala dostupna korisnicima. Planirano je da projekt obuhvati sva godišta tjednika. Tjednik je moguće zumirati i pohraniti na računalo. Novine su vjerno digitalizirane, međutim na pojedinim rubovima sadržaj nije čitljiv. ${ }^{53}$

Projekt digitalizacije nije istaknut na stranicama Knjižnice, već je o njemu moguće saznati putem pretraživača Google.

\section{Splitsko-dalmatinska županija}

Gradska knjižnica Kaštela

Na mrežnoj stranici Gradske knjižnice Kaštela navodi se kako je započeo projekt digitalizacije odabranih naslova iz Zavičajne zbirke. Projektom se želi olakšati dostupnost značajnije zavičajne građe. Digitalizirana baština okupljat će izbor najznačajnijih djela iz fonda Gradske knjižnice Kaštela prenesenih u digitalni oblik. Navodi se kako je prvi tako dostupan naslov reprint Pravilnika Društva Hrvatske čitaonice u Novome kod Trogira iz 1898. godine. Njemu možemo pristupiti putem pretraživača Google jer navedena poveznica na mrežnoj stranici još ne funkcionira. ${ }^{54}$

\section{Gradska knjižnica Solin}

Gradska knjižnica Solin digitalizira fond zavičajne zbirke Salonitane. Putem mrežne stranice Knjižnice možemo pristupiti digitalnoj zavičajnoj zbirci. Do sada je digitalizirano 10 zavičajnih zbirki. Građa je poprilično vjerno digitalizirana. Omogućeno je pretraživanje po ključnim riječima i zumiranje. ${ }^{55}$

\section{Gradska knjižnica Marka Marulića Split}

Putem stranice Gradske knjižnice Marka Marulića Split pristupa se digitaliziranoj zavičajnoj zbirci Spalatina. Projekt je započeo 2009. godine u okviru projekta digitalizacije arhivske, knjižnične i muzejske građe koji je pokrenulo Ministarstvo kulture Republike Hrvatske 2007. godine u suradnji s Nacionalnom i

\footnotetext{
53 Narodna knjižnica i čitaonica Vlado Gotovac Sisak. [citirano: 2016-04-16] Dostupno na http:// sisak.arhivpro.hr/.

54 Gradska knjižnica Kaštela. [citirano: 2016-04-16] Dostupno na http://www.gkk.hr/digitalizirana-bastina/.

55 Gradska knjižnica Solin. [citirano: 2016-04-16] Dostupno na http://www.knjiznicasolin.hr/ index.php/nasa-izdanja/digitalna-zavicajna-zbirka-salonitana.
} 
sveučilišnom knjižnicom u Zagrebu, Hrvatskim državnim arhivom i Muzejskim dokumentacijskim centrom. ${ }^{56}$

Projektom se korisnicima željelo približiti društvenu i kulturnu prošlost Splita i zaštititi izvornik od prekomjernog korištenja. Digitalizirana su djela splitskih autora i djela koja su tiskana u prvim splitskim tiskarama. Svaka od digitaliziranih jedinica ima dokumentarnu vrijednost i prikazuje društvenu i kulturnu prošlost Splita (slika 5). U fazi je pripreme i objavljivanje fotografija. ${ }^{57}$

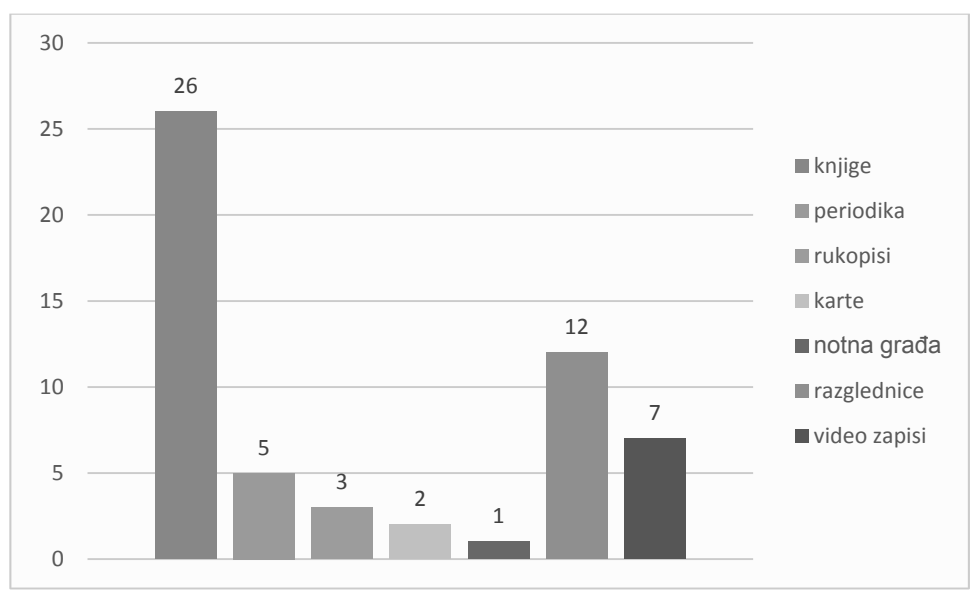

Slika 5. Digitalizirana građa u Gradskoj knjižnici Marka Marulića Split

Građa je vjerno digitalizirana. Doima se kao da se drži izvorna građa u rukama. Omogućeno je zumiranje i pretraživanje po ključnim riječima, ali nije moguće pohranjivanje na računalo. Sadrži i metapodatke. Videozapisi se u 4 slučaja nalaze putem servisa Vimeo, a u 3 slučaja putem YouTubea. Jedino fotografije nisu dostupne, a navodi se da su u fazi pripreme za objavljivanje. ${ }^{58}$

\section{Varaždinska županija}

\section{Gradska knjižnica i čitaonica Mladen Kerstner u Ludbregu}

Gradska knjižnica i čitaonica Mladen Kerstner digitalizirala je zbirku starih fotografija, razglednica i brošura pod imenom Podzemni hodnici Ludbrega te novine Ludbreški list. Razglednice je moguće učitati na mrežnim stranicama Knjižnice. ${ }^{59}$

\footnotetext{
56 Digitalizirana zavičajna zbirka Spalatina. [citirano: 2016-04-16] Dostupno na http://www. gkmm.hr/digitalizirana_bastina.htm.

57 Isto.

58 Isto.

59 Gradska knjižnica i čitaonica Mladen Kerstner, Ludbreg. [citirano: 2016-04-16] Dostupno na http://www.knjiznica-ludbreg.hr/zavicajna_zbirka.htm.
} 
Ludbreški list digitaliziran je u razdoblju od 1979. do 1989. godine. Digitaliziran je 91 broj. Novine su dostupne putem knjižničnog programa Metelwin, vjerno su digitalizirane i mogu se zumirati. ${ }^{60}$

\section{Gradska knjižnica i čitaonica Novi Marof}

Gradska knjižnica i čitaonica Novi Marof započela je 2010. godine s digitalizacijom Novomarofskog vjesnika. Digitalizirano je 12 brojeva. Knjižnica je digitalizirala i monografiju Tajne Grebengrada ili Posljednji grof od Zagorja. Digitalizirana građa dostupna je putem kataloga Crolista. Sadrži metapodatke, a moguće ju je zumirati i pohraniti na računalo. ${ }^{61}$

\section{Gradska knjižnica i čitaonica „Metel Ožegović”}

Gradska knjižnica i čitaonica „Metel Ožegović” digitalizirala je zavičajnu građu Warasdiniensia. U zbirci je dostupna građa koju možemo vidjeti u dijagramu (slika 6). ${ }^{62}$

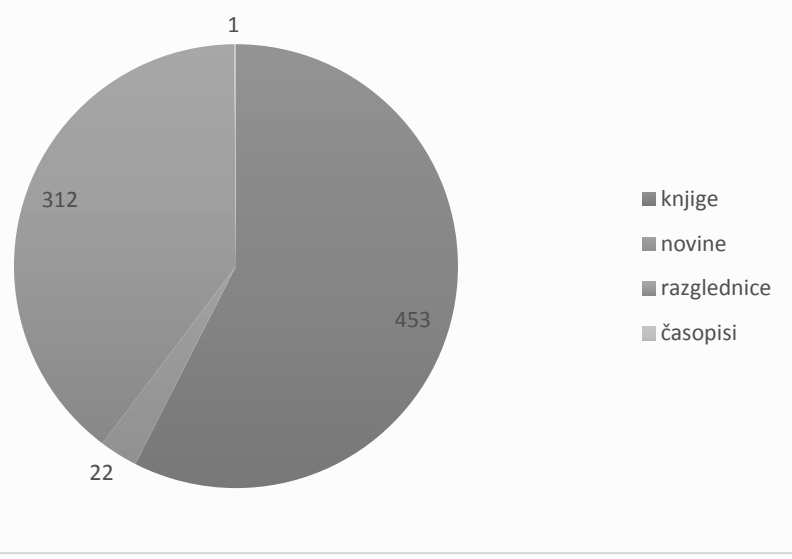

Slika 6. Digitalizirana građa u Gradskoj knjižnici i čitaonici „Metel Ožegović“

Mrežna stranica zbirke donekle je uređena, ali ju je još potrebno dopuniti podacima. Zbirci pristupamo putem knjižničnog programa Metelwin. Građu je moguće zumirati, ali joj tada kvaliteta slabi. ${ }^{63}$

60 Isto.

${ }_{61}$ Gradska knjižnica i čitaonica Novi Marof. [citirano: 2016-04-16] Dostupno na http://www. gknm.hr/arhiva-novosti.html.

62 Warasdiniensia - Digitalizirana zavičajna zbirka Gradske knjižnice i čitaonice „Metel Ožegović" Varaždin. [citirano: 2016-04-16] Dostupno na http://library.foi.hr/zbirke/varazdin/index. php?page=main.

63 Isto. 


\section{Virovitičko-podravska županija}

\section{Gradska knjižnica i čitaonica Virovitica}

Na mrežnoj stranici Gradske knjižnice i čitaonice Virovitica ne spominje se postojanje digitalizirane zavičajne zbirke. Međutim kada se u internetski pretraživač Google upiše pojam digitalizacije za navedenu knjižnicu, dobijemo odgovor da postoji digitalizirana građa. Sama mrežna stranica za digitaliziranu građu još je u nastajanju i nije do kraja uređena. ${ }^{64}$

Na mrežnoj stranici dostupne su nam 22 godine Virovitičkog lista koje su digitalizirane počevši od 1993., pa do 2014. godine. Inicijativu za digitalizaciju lokalnih novina pokrenula je 2013. godine ravnateljica Gradske knjižnice Višnja Romaj, prof. Virovitički list dio je knjižne građe Zavičajne zbirke Gradske knjižnice. Projektom se željelo sačuvati list za buduće generacije. S vremenom se želi postići da svi brojevi lista budu pretraživi u izvornom formatu. ${ }^{65}$

Pretraživanje je jednostavno. Samo se klikne na godinu izdanja lista i potom pretražujemo po brojevima. Dobra je vidljivost samih slova i ona se lako čitaju. Novine se mogu zumirati. Zbirci pristupamo putem knjižničnog programa Metelwin. ${ }^{66}$

\section{Vukovarsko-srijemska županija}

\section{Gradska knjižnica i čitaonica Vinkovci}

Gradska knjižnica i čitaonica Vinkovci pokrenula je postupak izgradnje digitalne zbirke 2008. godine. Zbirka se neprestano obogaćuje i nadopunjuje novim naslovima časopisa i knjiga, koje imaju velik utjecaj na lokalnu zajednicu, Vinkovce i Vukovarsko-srijemsku županiju. Nastoje se digitalizirati sadržaji iz Zavičajne zbirke Cibaliana, koje korisnici svakodnevno koriste. Njihovom digitalizacijom želi se, osim olakšavanja dostupnosti, produljiti trajanje materijalnih primjeraka naslova jer se tako manje koriste $i$, posljedično, manje oštećuju ${ }^{67}$

Knjižnica svojim najvećim projektom na polju digitalizacije smatra digitalizaciju Vinkovačkog lista. Projektom su digitalizirani svi brojevi novina s najduljom tradicijom izlaženja. Vinkovački list odabran je jer je od 1952. godine do danas ostao najvažnijim izvorom povijesti za Vinkovce. U digitalnoj zbirci nalazi se više od 47 tisuća jedinica kojima se može pristupiti besplatno. ${ }^{68}$

\footnotetext{
${ }^{64}$ Gradska knjižnica i čitaonica Virovitica. [citirano: 2016-04-18] Dostupno na http://www. knjiznicavirovitica.hr/.

65 Digitalizirana građa Gradske knjižnice i čitaonice Virovitica. [citirano: 2016-04-18] Dostupno na http://library.foi.hr/novine/d.aspx?C=130\&grupa=Gradska\%20knji\%9Enica\%20i\%20 $\%$ E8itaonica\%20Virovitica\&vrsta=VLA\&H=virovitica.

66 Isto.

67 Digitalizirana građa zbirke Gradske knjižnice i čitaonice Vinkovci. [citirano: 2016-04-18]

Dostupno na https://library.foi.hr/zbirke/vinkovci/index.php?page=oprojektu.

68 Isto.
} 
Od digitaliziranih knjiga dostupno je 37 naslova u digitalnoj zbirci Knjižnice. Od novina, osim Vinkovačkog lista, na mrežnoj stranici Knjižnice možemo vidjeti kako su započeti projekti digitalizacije novina Cibalis, Cibalis: List za zbilju, šalu i satiru i Hrvatski branik: Nezavisni tjedni informativni list. ${ }^{69}$

Knjige su dostupne putem knjižničnog programa Metelwin. Omogućeno je zumiranje i pretraživanje prema ključnim riječima, međutim ne mogu se pohraniti datoteke. Građa je pregledna i dobro vidljiva. Novine su lako pretražive po godini izdanja i brojevima. ${ }^{70}$

\section{Zadarska županija}

\section{Gradska knjižnica Zadar}

Na mrežnoj stranici Gradske knjižnice Zadar pronalazimo projekt digitalizacije Delmata. Projekt je započeo 2009. godine, a odnosi se na stvaralaštvo Ljube Stipišića Delmate. Projektom se željelo sačuvati njegov opus kao važan dio hrvatske glazbene baštine. Delmatin opus važan je ponajviše zbog muzikološkog i kulturološkog značaja te za gradnju i očuvanje identiteta južne Hrvatske. Služi za upoznavanje hrvatske glazbene baštine, istraživanje i eksperimentiranje te kao inspiracija za kreativni rad. U ostvarenju projekta pomoglo je Ministarstvo kulture Republike Hrvatske i Raiffeisen banka. ${ }^{71}$

$\mathrm{Na}$ mrežnim stranicama dostupna je građa koju možemo vidjeti u dijagramu (slika 7). ${ }^{72}$

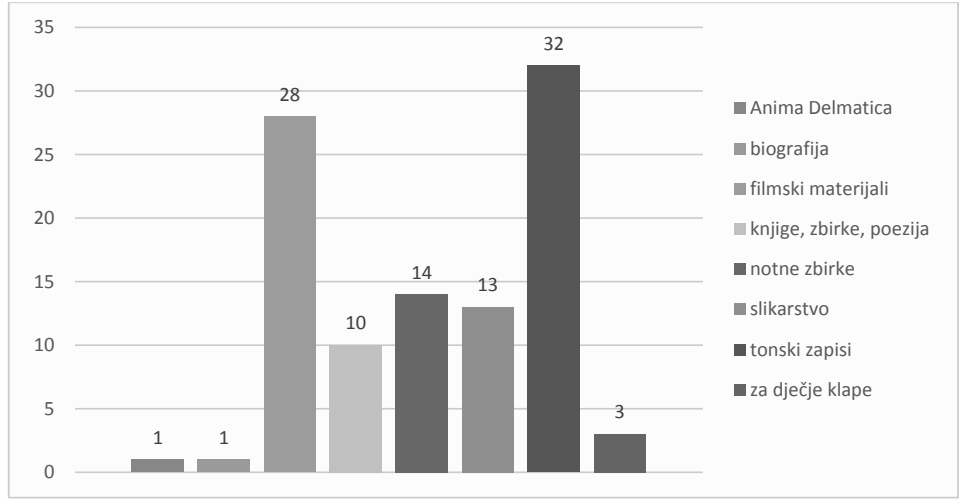

Slika 7. Digitalizirana građa u Gradskoj knjižnici Zadar

Građu je moguće zumirati, pretraživati po ključnim riječima i pohraniti na računalo. ${ }^{73}$

\footnotetext{
69 Isto.

70 Isto.

72 Isto.

73 Isto.
}

71 Delmata Gradska knjižnica Zadar - projekt digitalizacije. [citirano: 2016-04-18] Dostupno na http://www.delmata.org/o-projektu. 


\section{Zagrebačka županija}

\section{Gradska knjižnica Samobor}

Gradska knjižnica Samobor pod izbornikom Digitalni arhiv ima poveznicu na stranicu za objavljivanje digitalnih zbirki Knjižnice. ${ }^{74}$ To je testna verzija sustava. Na mrežnoj stranici trenutno se nalaze Samoborske novine. Knjižnica se odlučila na projekt digitalizacije jer je željela približiti zavičajnu kulturnu baštinu i korisnicima izvan Knjižnice. Digitalizirani su brojevi od 1950. do 1971. godine. ${ }^{75}$

Vidi se da je potrebna dorada mrežne stranice. Pojedine primjerke teže je čitati zbog starosti samih novina, ali sama građa dosta je vjerno digitalizirana. Novine je moguće zumirati, a za preuzimanje je potrebno zatražiti pismenu dozvolu Knjižnice. $^{76}$

\section{Šibensko-kninska županija}

Gradska knjižnica „Juraj Šižgorić”

Gradska knjižnica „Juraj Šižgorić” Šibenik digitalizirala je 8 časopisa i 33 novine. Kad su u pitanju novine, važno je spomenuti da su digitalizirana sva godišta Hrvatske rieči, najstarijih šibenskih novina. One su izlazile od 1905. do 1914. godine. Nakon Hrvatske rieči, u prvi projekt digitalizacije 2009. godine ubrajaju se i novine Hrvatska misao, Narodna straža i Naprednjak. ${ }^{77}$

Knjižnica se odlučila za digitalizaciju jer je željela približiti i dati na proučavanje lokalnu povijest u prvoj polovici 20. stoljeća. Građa je poprilično vjerno digitalizirana. Moguće je zumiranje, pretraživanje po ključnim riječima i pohranjivanje na računalo. Jedino se u pojedinim primjercima slabo vide slova zbog starosti samih novina. ${ }^{78}$

\section{Grad Zagreb}

Knjižnice grada Zagreba

Digitalizirana zagrebačka baština projekt je Knjižnica grada Zagreba. Na jednom mjestu možemo pristupiti vrijednoj i rijetkoj građi pohranjenoj u odjelima Knjižnice. Cilj je projekta upoznati korisnike sa zagrebačkom kulturnom i znanstvenom baštinom te popularizirati građu za korištenje izvan Knjižnice. Želi se potaknuti širu javnost na prepoznavanje kulturne baštine grada i važnost očuvanja

74 Gradska knjižnica Samobor. [citirano: 2016-04-18] Dostupno na http://www.gks.hr/.

75 Samoborske novine. [citirano: 2016-04-18] Dostupno na http://digital.arhivpro.hr/samobor/ index.php.

76 Isto.

77 Gradska knjižnica „Juraj Šižgorić“ Šibenik. [citirano: 2016-04-18] Dostupno na http://www. knjiznica-sibenik.hr/.

78 Isto. 
kulturnog i vizualnog identiteta. Projekt je započet 2008. godine u sklopu projekta „Osvijetlimo dio svoga nasljeđa: Zagreb na pragu modernog doba“ koji je podržalo Ministarstvo kulture. ${ }^{79}$

Sva digitalizirana građa dostupna je u Katalogu KGZ-a kroz nakladničke cjeline:

a) Zagreb na pragu modernog doba

b) Izdanja zagrebačkih tiskara 17. i 18. stoljeća

c) Iz opusa Dragutina Domjanića

d) Ilirci

e) Priznanja zagrebačkih društava. ${ }^{80}$

Na mrežnim stranicama navedena je digitalizirana građa koju možemo vidjeti u dijagramu (slika 8$).{ }^{81}$

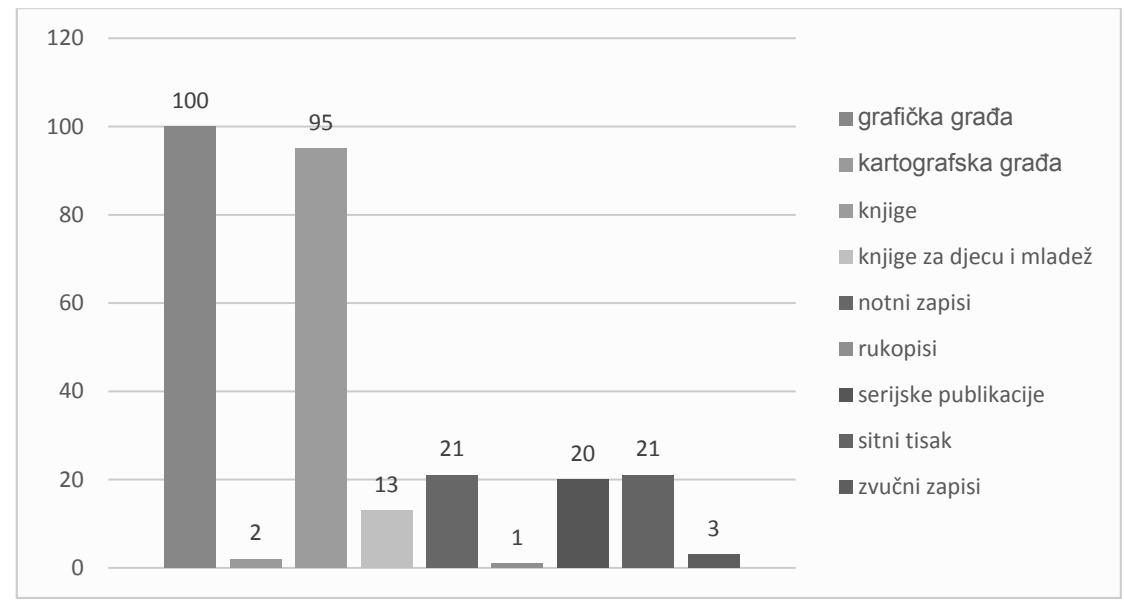

Slika 8. Digitalizirana građa u Knjižnicama grada Zagreba

Mrežna stranica dobro je organizirana i laka za snalaženje. Građa sadrži metapodatke, vjerno je digitalizirana, a moguće je zumiranje i pohranjivanje datoteka. ${ }^{82}$

\footnotetext{
79 Digitalizirana zagrebačka baština. [citirano: 2016-04-18] Dostupno na http://kgzdzb.arhivpro. $\mathrm{hr} /$.

80 Isto.

81 Isto.

82 Isto.
} 


\subsection{Rasprava}

Smatramo izrazito pozitivnim to što su hrvatske narodne knjižnice prepoznale važnost digitalizacije i odlučile učiniti svoju građu dostupnom online putem. To se najbolje očituje u projektima digitalizacije koji su započeli u svim većim narodnim knjižnicama u hrvatskim županijama. Pozitivnim također smatramo i to što je u Koprivničko-križevačkoj, Splitsko-dalmatinskoj i Varaždinskoj županiji prepoznata važnost digitalizacije te su one započele postupke digitalizacije u tri narodne knjižnice.

Postupak digitalizacije jedino nije započeo u Ličko-senjskoj županiji, dok Međimurska županija nema digitaliziranu građu na mrežnim stranicama knjižnica, ali je započela s pripremama za digitalizaciju.

Iz analize i digitalnih zbirki narodnih knjižnica u Hrvatskoj možemo vidjeti da se najviše digitalizirane građe odnosi na fotografije i razglednice (2314 primjeraka). Razlog je tomu što je njih najlakše digitalizirati jer su malog formata i većinom ne podliježu ograničenjima autorskih prava. Nakon njih su po zastupljenosti dostupni 821 knjiga i 363 naslova novina. Najviše raznovrsne građe digitalizirano je u Knjižnicama grada Zagreba i Gradskoj knjižnici Marko Marulić Split. To nas ne treba čuditi jer su to dva najveća Hrvatska grada i regionalna središta koja imaju najveći izvor financija.

\section{Zaključak}

Uloge narodnih knjižnica u današnje su vrijeme brojne. One su obrazovne, kulturne i informacijske ustanove koje pružaju pristup sustavno organiziranu znanju, čime pridonose napretku društva. Zahvaljujući narodnim knjižnicama pojedinac širi svoje vidike, oblikuje svoje mišljenje i stječe vlastito stajalište. Te su mogućnosti knjižnica dodatno proširene primjenom informacijske i komunikacijske tehnologije i stvaranjem digitalnih zbirki. Brojne narodne knjižnice u Hrvatskoj započele su s postupcima digitalizacije knjižničnih zbirki kako bi sačuvale krhku i unikatnu građu, ali i učinile dostupnom građu popularnu među korisnicima. Digitalizacijom građe u svojim fondovima narodne knjižnice nastoje privući i zadržati korisnike koje privlače drugi mediji poput interneta i televizije.

U Hrvatskoj su najčešći započeti projekti digitalizacije knjižničnih zbirki specifični za pojedino zemljopisno područje. Njihovom digitalizacijom knjižnice su željele prikazati građu koju čuvaju, ali i istaknuti svoj kulturni identitet. Također su nastojale pokazati osobitosti i bogatstvo fondova koje posjeduju te tako pridonijeti promociji kraja u kojem djeluju. Relativno mali broj dostupnih digitalnih zbirki u odnosu na ukupni broj narodnih knjižnica u Hrvatskoj ukazuje na mogućnosti pokretanja novih projekata digitalizacije građe. Takve će vrste aktivnosti ovisiti o brojnim čimbenicima poput dostupnih financijskih sredstava, dostupne 
opreme, ljudskih resursa, ali i stanja građe koju je potrebno digitalizirati. Ciljeve koje su narodne knjižnice postavile u svojim planovima i programima povezanim s digitalnom građom neće biti lako ostvariti, ali je to ipak moguće uz mnogo truda i, pogotovo, učenja o dobrim i lošim stranama postojećih digitalnih zbirki u narodnim knjižnicama.

\section{LITERATURA}

Digital collection. [citirano: 2017-04-20]. Dostupno na http://smw-rda.esc.rzg.mpg.de/ index.php/Digital_Collection

Digitization. [citirano: 2017-04-20]. Dostupno na http://www.businessdictionary.com/ definition/digitization.html

IFLA/Unesco Manifest za narodne knjižnice. // Vjesnik bibliotekara Hrvatske 55, 2(2012), str. 193-196.

Lagoze, Carl; Fielding, David. Defining collections in distributed digital libraries. // D-Lib magazine. 4, 11(1998). [citirano: 2017-04-20]. Dostupno na http://www.dlib. org/dlib/november98/lagoze/11lagoze.html.

Lee, Hur-Li. What Is a Collection? // Journal of the American society for information science 51, 12(2000), 1106-1113.

Portal narodnih knjižnica. [citirano: 2016-04-16] Dostupno na http://www.knjiznica.hr/ mods/knjiznice/?zupanija $=9$

UNESCOv manifest za narodne knjižnice 1994. [citirano: 2015-12-03] Dostupno na http://dzs.ffzg.unizg.hr/text/UNESCOv_manifest_za_narodne_knjiznice.htm

Vrana, Radovan. Vidovi organizacije digitalizacije građe u knjižnicama visokoškolskih ustanova Sveučilišta u Zagrebu. // Vjesnik bibliotekara Hrvatske 55, 2(2012), 4164.

\section{Mrežne stranice knjižnica}

Brodensia, zavičajna zbirka. [citirano: 2016-05-11] Dostupno na http://www.brodensia. hr/index.php/o-projektu

Delmata Gradska knjižnica Zadar - projekt digitalizacije. [citirano: 2016-04-18] Dostupno na http://www.delmata.org/o-projektu

Digitalizirana građa zbirke Gradske knjižnice i čitaonice Vinkovci. [citirano: 2016-0418] Dostupno na https://library.foi.hr/zbirke/vinkovci/index.php?page=oprojektu

Digitalizirana građa Gradske knjižnice i čitaonice Virovitica. [citirano: 2016-04-18] Dostupno na http://library.foi.hr/novine/d.aspx 
Digitalizirana zagrebačka baština. [citirano: 2016-04-18] Dostupno na http://kgzdzb. arhivpro.hr/

Digitalizirana zavičajna zbirka Spalatina. [citirano: 2016-04-16] Dostupno na http:// www.gkmm.hr/digitalizirana_bastina.htm

Dubrovačke knjižnice Dubrovnik. [citirano: 2016-04-14] Dostupno na http://www.dkd. $\mathrm{hr} /$ index.php?option $=$ com_content\&view $=$ article\&id $=355 \&$ Itemid $=192$

Gradska i sveučilišna knjižnica Osijek. [citirano: 2016-02-15] Dostupno na http://www. gskos.unios.hr/?upit=sadrzaj\&id=191

Gradska knjižnica „Ivan Goran Kovačić“. [citirano: 2016-04-14] Dostupno na http:// www.gkka.hr/?page_id=975

Gradska knjižnica „Franjo Marković“ Križevci. [citirano: 2016-04-14] Dostupno na http://www.knjiznica-krizevci.hr/html.asp?id=1310

Gradska knjižnica „Juraj Šižgorić“ Šibenik. [citirano: 2016-04-18] Dostupno na http:// www.knjiznica-sibenik.hr/

Gradska knjižnica Kaštela. [citirano: 2016-04-16] Dostupno na http://www.gkk.hr/digitalizirana-bastina/

Gradska knjižnica Krapina. [citirano: 2016-04-16] Dostupno na http://krapina.arhivpro. hr/index.php

Gradska knjižnica Poreč. [citirano: 2016-04-14] Dostupno na http://porec.arhivpro.hr/ index.php

Gradska knjižnica Samobor. [citirano: 2016-04-18] Dostupno na http://www.gks.hr/

Gradska knjižnica Slavonski Brod. [citirano: 2016-05-11] Dostupno na http://www. gksb.hr/

Gradska knjižnica Solin. [citirano: 2016-04-16] Dostupno na http://www.knjiznicasolin. $\mathrm{hr} /$ index.php/nasa-izdanja/digitalna-zavicajna-zbirka-salonitana

Gradska knjižnica i čitaonica Virovitica. [citirano: 2016-04-18] Dostupno na http:// www.knjiznicavirovitica.hr/

Gradska knjižnica i čitaonica Ivana Belostenca. [citirano: 2016-04-14] Dostupno na http://www.gkc-ivanabelostenca.hr/index.php/o-nama

Gradska knjižnica i čitaonica Mladen Kerstner, Ludbreg. [citirano: 2016-04-16] Dostupno na http://www.knjiznica-ludbreg.hr/zavicajna_zbirka.htm

Gradska knjižnica i čitaonica Novi Marof. [citirano: 2016-04-16] Dostupno na http:// www.gknm.hr/arhiva-novosti.html

Gradska knjižnica i čitaonica Požega. [citirano: 2016-02-15] Dostupno na http://www. gkpz.hr/digitalna-bastina/

Književna baština R. F. Magjera. [citirano: 2016-02-15] Dostupno na http://magjer. gskos.hr/ 
Knjižnica i čitaonica Grada Preloga. [citirano: 2016-04-16] Dostupno na http://knjiznica-prelog.webs.com

Knjižnica Fran Galović Koprivnica. [citirano: 2016-04-14] Dostupno na http://www. knjiznica-koprivnica.hr/knjiznica/defaultcont.asp?id=11\&n=5

Narodna knjižnica „Petar Preradović““ Bjelovar. [citirano: 2016-04=13] Dostupno na http://www.knjiznica-bjelovar.hr/index.php/o_nama/

Narodna knjižnica i čitaonica Vlado Gotovac Sisak. [citirano: 2016-04-16] Dostupno na http://sisak.arhivpro.hr/

Novinstvo Đurđevca. Gradska knjižnica Đurđevac. [citirano: 2016-04-14] Dostupno na http://library.foi.hr/dj/upit.aspx

Samoborske novine. [citirano: 2016-04-18] Dostupno na http://digital.arhivpro.hr/samobor/index.php

SVeVID digitalna knjižnica. [citirano: 2016-04-16] Dostupno na https://svevid.locloudhosting.net/

Virtualna zavičajna zbirka. Projekt Gradske knjižnice i čitaonice Pula. [citirano: 201604-14] Dostupno na http://vizz.gkc-pula.hr/hr/o-projektu/

Warasdiniensia - Digitalizirana zavičajna zbirka Gradske knjižnice i čitaonice „Metel Ožegović" Varaždin. [citirano: 2016-04-16] Dostupno na http://library.foi.hr/zbirke/ varazdin/index.php?page $=$ main 